\title{
Macroeconomic adjustment and heterogeneity in the euro area
}

\author{
Andrzej Torój*
}

11th September 2008

\begin{abstract}
In this paper, we revisit the subject of country-level macroeconomic adjustment in the euro area in the absence of autonomous monetary and exchange rate policy. We discuss how the real interest rate mechanism and the competitiveness (real exchange rate) channel interact with various aspects of countries' heterogeneity. Our stylized New Keynesian model of a structurally heterogenous monetary union comprises country-specific empirical hybrid IS and Phillips curves and common Taylor rule. It extends the standard closed-economy specification and replicates both effects in question. Cross-country long-term differentials in steady-state inflation (due to structural factors, such as Balassa-Samuelson effect) and natural interest rate do not rule out the existence of an equilibrium, as long as they are offset by additional price level differentials. We establish a link between the smoothness of the adjustment process and various aspects of countries' heterogeneity, such as expectation formation mechanisms, inflation persistence, market flexibility, as well as output gap sensitivity to real interest rate, real exchange rate and foreign demand.

Our GMM estimates of the IS and Phillips curves imply that the competitiveness channel is effectively at work in EMU 12 in the sense of real exchange rate influence on the output gap, but market flexibility necessary to trigger shifts in REER remains below the standards in New Keynesian empirical literature. They also suggest that the risk of the real interest rate effect is reduced by low output gap responsiveness to country-specific real interest rates, coupled with mostly significant responses to real exchange rates, and mainly results from intrinsic inflation persistence. Our model does not confirm the existence of a premium when foreign markets are more rigid in relative terms. Promoting market flexibility, combating intrinsic inflation persistence, anchoring inflation expectations and intensifying trade linkages remain the main challenges for policymakers willing to minimize the procyclical effects of real interest rate and maximize the efficiency of competitiveness channel as a substitute for autonomous monetary policy.
\end{abstract}

\section{Introduction}

Over the recent years, much research attention has been concentrated on the adjustment process after asymmetric shocks hitting a single country in a monetary union. This is obviously due to launch of the euro area in 1999. A common monetary policy spans there a set of countries exhibiting a high degree of heterogeneity. Structural cross-country differentials increase the probability of asymmetric demand and supply shocks and imply asymmetric propagation of common shocks. As these cannot be absorbed on the national level via autonomous monetary policy or nominal

*National Bank of Poland (Bureau for the Integration with the Euro Area, andrzej.toroj@mail.nbp.pl) and Warsaw School of Economics (andrzej.toroj@doktorant.sgh.waw.pl). The views expressed are those of the author and do not necessarily reflect those of the institutions he is affiliated with. The author is grateful to Marek Rozkrut whose involvement was critical to successful completion of this study, and to Jochen Blessing, Marcin Kolasa, Michał Konopczak, Eric Leeper and Cezary Wójcik for valuable comments and suggestions. The paper has also benefited from comments by seminar participants at the National Bank of Poland and 12th International ZEI Summer School in Bad Honnef. 
exchange rate dynamics, smooth adjustment of inflation and output to their equilibrium values challenges other macroeconomic mechanisms to a greater extent.

Two most widely discussed ones are real interest rate effect and competitiveness channel. The former is not an adjustment channel in the strict sense, but it results from the membership in a monetary union and belongs to macroeconomic process induced by asymmetric developments. Common nominal interest rates, possibly decoupled from country-specific equilibrium levels, act procyclically in the short run in the presence of inflation differentials. The latter channel is expected to provide an economy with a stabilizing force in the long run, but the timing and efficiency of this stabilization remains vague in the up-to-date empirical literature. Both mechanisms are widely discussed in the context of empirically persistent inflation differentials in EMU, inducing significant competitiveness shifts on the one hand and translating into heterogenous inflation expectations on the other.

Why should inflation rates differ in a persistent way? ${ }^{1}$ First of all, this can be a result of an asymmetric shock hitting only a subset of currency area economies. Asymmetric shocks have attracted much attention in the OCA literature (de Grauwe, 2005). Section 3 presents a survey of the literature on EMU attempting at identifying such shocks. ${ }^{2}$ From our point of view, consequences of such asymmetric developments for expected and actual inflation are essential. In the model considered in this paper, two types of asymmetric shocks are incorporated: demand shocks as disturbances tof the output gap (translating later into inflationary pressure within the model) and supply shocks as exogenous cost-push shifts in inflation, in the spirit of basic New Keynesian model (e.g. Clarida et al., 2001).

Secondly, even common shocks can be propagated in a different way due to cross-country structural differentials. Such an economic heterogeneity is, to a greater or lesser extent, an intrinsic feature of any currency area. EMU, however, as a currency union of politically independent countries attracts particual attention. Cross-country heterogeneity is discussed both from the ECB perspective (how to cunduct a common monetary policy and whether one size fits all, see e.g. Brissimis and Skotida, 2008) and a single country standpoint (whether the ECB policy is suitable for an economy, see Calmfors, 2007). However, macroeconomic divergence in a monetary union is also, to an extent, an artefact of effective adjustment mechanisms at work. Traistaru-Siedschlag (2006), Roubini et al. (2007), Lane (2006) and Wójcik (2008) discuss the issue of cross-country differentials being both a source and a consequence of adjustment processes considered here. Our GMM estimates of hybrid IS and Phillips curves, reflecting to some extent the up-to-date experience of the monetary union, cover a relatively wide range of parameter values over countries and imply various adjustment speed and loss in terms of output gap and inflation variance.

Thirdly, structural issues (e.g. Balassa-Samuelson effect) can imply long-run differentials. As such, they should not be part of the analysis in this context. In our model, persistent differentials in expected inflation or even in natural interest rates allow the system to remain stable, provided that their effect on output gap are counterbalanced by over- or undervalued real exchange rates. This implies a switch to a new steady state, with common nominal interest rate and a correction in equlibrium price level differentials, once a country joins a currency union.

From the perspective of a country planning to join the euro area, two questions arise in this context: (i) is the real interest rate effect posing a threat to macroeconomic stability of an economy and what does historical experience of EMU countries tell us about this and (ii) under which conditions is the competitiveness channel going to be effective and how long and costly is it going to take for an asymmetric shock to be absorbed. Theoretical and empirical assessment of these questions is the main motivation of this paper. Building on the New-Keynesian framework, we set up a simple model that allows us to replicate the main features of macroeconomic adjustment in the aftermath of asymmetric shocks, described in the literature on EMU. We also take an empirical look at the main determinants of the adjustment path. Mechanisms such as competitiveness

\footnotetext{
${ }^{1} \mathrm{~A}$ vast battery of literature is focused on inflation differentials in EMU. In-depth treatment can be found e.g. in European Central Bank (2003); Honohan and Lane (2003, 2004); Angeloni and Ehrmann (2004); European Central Bank (May 2005); Altissimo et al. (2005); Canzoneri et al. (2005); Hofmann and Remsperger (2005); Beck et al. (2006); MacDonald and Wójcik (2006).

${ }^{2}$ For a typology of shocks, see e.g. Borowski (2001).
} 
channel, trade linkages, rationality of expectations and - to a various extent - common monetary policy ensure effective stabilisation of the output gap after an asymmetric shock, but the speed of adjustment depends on the degree of forward-lookingness in the economy, market flexibility, openness of economies and strength of monetary transmission. The risk and size of real interest rate effect depends on both output gap responsiveness to country-specific real interest rate and the mechanism of forming expectations, whereby estimates of the appropriate parameter are often insignificant. The real exchange rate channel can be disentangled into (i) inflation responsiveness to output gap - empirically sluggish in most of the euro area countries and (ii) output gap responsiveness to real exchange rate over- or undervaluation, whose estimates remain on the optimistic side. This should also partly immunize the economies to real interest rate effect, even in the short run.

The paper is organized as follows. Section 2 presents both channels in detail, and reviews the aspects of heterogeneity that matter for the adjustment dynamics. A survey of empirical literature on asymmetric macroeconomic developments in EMU is presented briefly in Section 3. Section 4 develops a simple New-Keynesian model for a monetary union, encompassing both channels in question. GMM estimates of the parameters are presented in section 5. Section 6 discusses consequences of heterogeneity in key parameter values for the adjustment process and section 7 concludes.

\section{Macroeconomic adjustment in a heterogenous currency union}

We analyze the adjustments to asymmetric developments within a model encompassing two major mechanisms discussed in the literature: real interest rate channel (subsection 2.1) and real exchange rate channel (subsection 2.2). The former is not indeed an adjustment mechanism, as it acts procyclically and is expected to boost the amplitude and persistence of asymmetric shocks. It must be, however, taken into consideration as a potential impediment to smooth adjustment dynamics, especially in an environment where persistent inflation differentials potentially translate into heterogenous inflation expectations across countries. In the following two subsections, we shortly summarize the main idea of both mechanisms, along with methodological difficulties arising around them. We leave beyond the scope of this paper a number of other adjustment mechanisms, such as risk sharing in financial markets ${ }^{3}$, fiscal policy instruments ${ }^{4}$ or labour market mobility. The last one is generally considered to play a limited role between the euro area countries. Although we do not explicitly model or discuss labour market flexibility here, one can treat it as a necessary condition for a quick response of prices to output gap.

\subsection{Real interest rate channel}

Enumerating real interest rate channel among adjustment mechanisms within a monetary union is indeed misleading: it is, at least at the theoretical level, an "automatic destabiliser". Its work, however, needs to be taken into account when smoothness of adjustment within a monetary union is evaluated. The roots of the debate date back to Wicksell (1907) who considers an inherent instability of prices when banks' nominal rate would be fixed below or above its "normal" level for some reason. He argues they would be rising to infinity or converging towards zero, respectively. What he called an "abstract statement" comparable with the collapse of the Solar System as Sun's attraction ceases (as there is no reason to try this out), came back in the context of european monetary integration. Walters (1994) argued that liberalizing capital flows within a monetary union would equalize short-term nominal rates across the union (a fact that we are accustomed $e x$ post to consider obvious) which would reduce the real interest rate in a country with high inflation, inducing even more demand-side pressure on prices and hence further boosting inflation ("Walters critique").

\footnotetext{
${ }^{3}$ See e.g. Asdrubali et al. (1996); Kalemli-Ozcan et al. (2001, 2003, 2004); Imbs (2004); Afonso and Furceri (2007).

${ }^{4}$ See Hoeller et al. (2002).
} 
Figure 1: Real interest rate mechanism

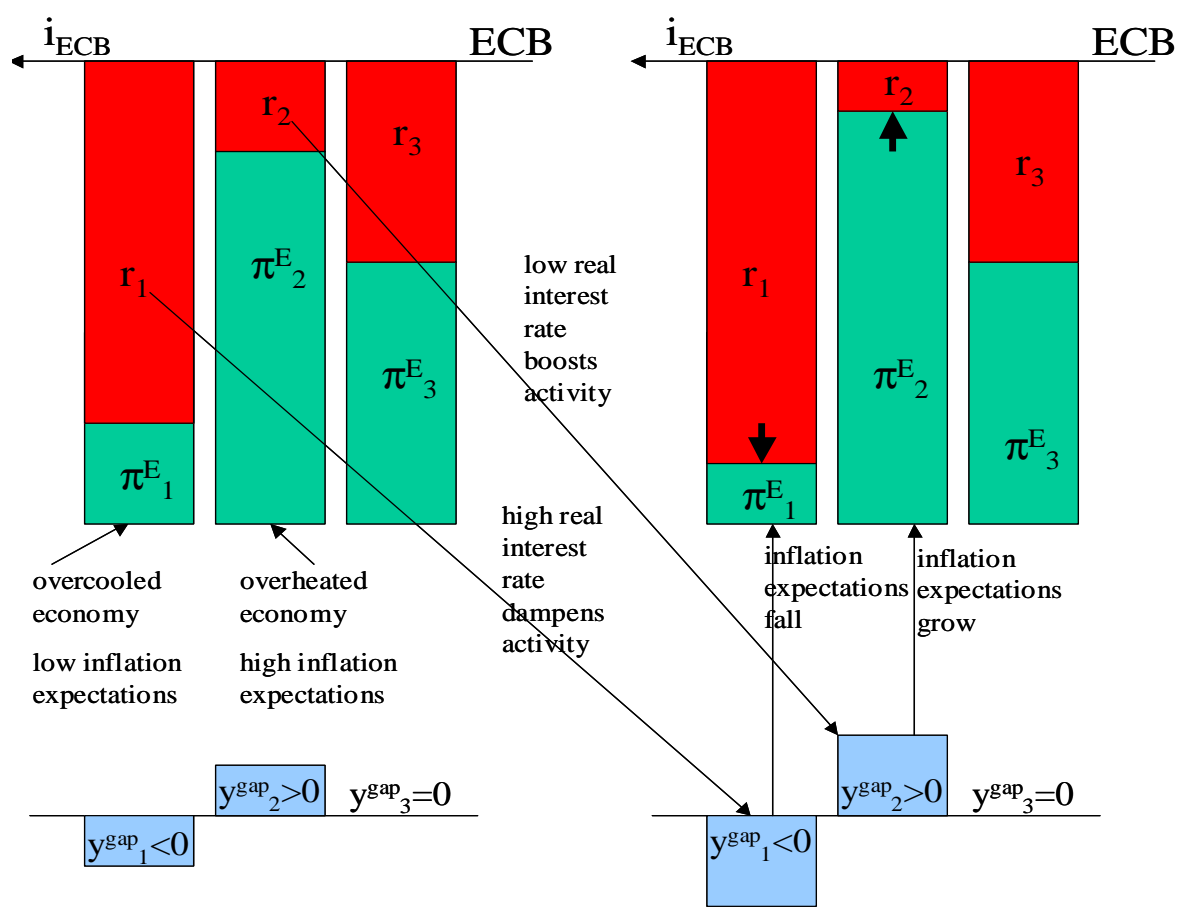

Source: author

Contemporary understanding of the real interest rate mechanizm as procyclical channel on the country level in a monetary union, as in Lane (2006), European Commission (2006), Roubini et al. (2007), Wójcik (2008), remains in line with the main logic of Wicksell and Walters. As in ordinary IS curve, output gap increases (decreases) as real interest rate falls (grows) as households are more (less) motivated to raise today's consumption, producers find more (less) incentive to invest, a rise in discount factor raises the wealth of households and improves balance sheet positions of firms, providing them with further incentives to consume or invest. ${ }^{5}$ Real interest rate is the cost of consuming or investing today instead of tomorrow; borrowing money for this consumption at nominal rate of interest is a cost partially offset by the loss of its value over this period, evaluated at the time of decision making (inflation expectations). When money depreciates at a various pace across countries (inflation differentials), inflation expectations are closely linked to country level inflation rates and short-term nominal rate remains equal, real rates vary. A high inflation economy experiences therefore lower real interest rates, which - within the IS curve framework raise the pace of product growth over potential and causes additional inflationary pressure (see Figure 1 for a stylized scheme).

Deroose et al. (2004) also suggest that cycles could be amplified by myopic and current sentiment determined behaviour of economic agents in assessing profitability of investment project and consumption prospects: in a period of overheating it is too optimistic (as producers extrapolate their products' favourable price developments into the future and consumers expect further dynamic wage growth), in an undercooled economy - too pesimistic. Empirically, this argument remains in line with real interest rate effect described above. The authors additionally discuss the link between macroeconomic and financial cycle, emphasizing the reinforcing effect of the latter on the former one.

Does this inherent instability have to be effectively at work? Not necessarily, at least for 3 reasons.

1. Firstly, economic agents do not know ex ante how much money will depreciate and hence

\footnotetext{
${ }^{5}$ Deroose et al. (2004) suggest that wealth effect is of particuar importance in this context.
} 
what the real cost of the acceleration in consumption or investment will be. What we know ex post as observable difference between nominal interest rate and inflation rate (ex post real interest rate) remains unknown for the agents at the time when they make decisions that determine the level of output. Their choices depend in fact on the current nominal rate and their inflation expectations. Higher inflation at present does not mean that inflation expectations, relevant for the ex ante real interest rate, are also higher. This might be the case when expectations are static, which is accompanied by a high degree of intrinsic inflation persistence. However, a number of authors (Woodford, 2006; Benati, 2008; PisaniFerry et al., 2008; Calmfors and Johansson, 2002) suggest that, in a monetary regime such as EMU, intrinsic persistence is endogenously losing significance and inflationary expectations are well anchored. According to the European Commission (2006) that compares ex post and $e x$ ante approach ${ }^{6}$, ex ante real interest rates exhibit less dispersion over countries and decline in their dispersion in the first years of EMU was more marked. However, the issue of expectations measurement leaves this field open for discussion.

2. Secondly, differentials in inflation across EMU member coutnries partially result from structural factors, such as the catching-up process in some of the economies. Due to BalassaSamuelson effect and price level convergence, these economies may experience higher inflation and therefore lower interest rates. At the same time, catching-up countries are considered to have higher natural interest rates with higher marginal productivity of capital. This would suggest that the real interest rate mechanism could even be more pro-cyclical given this aspect of heterogeneity, even if inflation expectations were homogenous. Although there are many publications dealing with the natural rate of interest within the euro area, the question of natural rate variability across its member states and its consequences is not yet explored in depth. ${ }^{7}$

3. Thirdly, the real interest rate mechanism is based on the assumption that there is a countryspecific real rate of interest is based on country-specific inflation expectations:

$$
r_{j, t}=\frac{1+i_{E B C, t}}{1+E_{t} \pi_{j, t+1}}-1 \approx i_{E B C, t}-E_{t} \pi_{j, t+1}
$$

with $j$ indexing countries. Rising degree of economic and financial integration within EMU puts a question mark over Formula (1). As European Commission (2006) suggests, development of risk sharing, foreign trade and internalization of ECB's inflation target among economic agents may reduce their national focus. All this would lead, in an extreme case, to homogenous inflation expectations and hence a single real interest rate in EMU. Evidence from empirical research reported so far remains mixed. On the one hand, Arnold and Lemmen (2006) found stronger dependence of inflation expectations on country-specific past inflation rates than euro-area inflation target. On the other hand, Hofmann and Remsperger (2005) find that other countries' real interest rates may matter directly for one state's output gap and von Hagen and Hofmann (2004) find a significant role of the EMU-wide (and not country-specific) ex post real interest rate in countries' backward-looking IS curves.

Further methodological difficulties include the following issues:

- Heterogeneity of agents with respect to basis for inflation expectations can be assumed, as suggested by the European Commission (2006, p. 138): CPI for consumers, PPI for producers, foreign CPI or PPI for exporters. This additionally complicates the analysis.

- Further doubts are raised by arbitrary choice of short-term market interest rates, strongly influenced by common monetary policy. European Commission (2006) suggests long-term interest rates as another possibility, especially in economies where long-term financing plays a dominant role. However, given the institutional setup of the euro area monetary policy, there is also no reason for for long rates to diverge (Wójcik, 2008).

\footnotetext{
${ }^{6}$ Using headline inflation and Consensus Economics forecast average respectively.

${ }^{7}$ Catao and Mackenzie (2006) provide 'implicit equilibrium interst rates' based on Gordon equation.
} 
- Equality of nominal interest rates really faced by economic agents is questioned as well. Single policy rate, almost identical money market rates and strongly converged bond yields do not yet imply homogenous financing conditions for retail customers. As European Central Bank (2006) shows, there are persistent and nonnegligible differences in loan and deposit rates, leading e.g. to higher rates in Greece, Portugal and Italy. According to the calculations of the European Commission (2006), however, this source of variability is much less significant for the country-specific ex post real rates than inflation differentials.

All these caveats render the mechanism difficult to measure and verify empirically. Nonetheless, there are theoretical and empirical analyses suggesting which countries have already been or could potentially be exposed to negative influence of this mechanism. The ECB nominal rate reaction depends on the area-wide conditions. Theoretically, this creates a risk of destabilization, mainly in low-weighting economies (Hoeller et al., 2002). Roubini et al. (2007) also point to countries with a high degree of intrinsic inflation persistence as candidates for overheating or overcooling. According to Deroose et al. (2004), labour and product market rigidities are potentially supportive factors for the size and dynamics of temporary cycle amplification via the real interest rate channel.

Finally, many of the authors mentioned above suggest that relative importance of the real interest rate channel is expected to decline as endogenous changes in EMU economies progress: uniformization of monetary transmission mechanisms and internalization of ECB policy by economic agents could reduce heterogeneity in inflation expectations and inflation rates themselves, business cycle synchronization should rise, intra-EMU trade increase and risk sharing mechanisms develop. However, the findings of Arnold and Kool (2004) with respect to the US economy (see Section 3) raise some doubts over complete negligibility of this channel in the long run.

\subsection{Competitiveness channel}

Competitiveness channel is an automatic stabilizer, counterbalancing the overheating or overcooling effect of real interest rate effect described in subsection 2.1. As part of market-based adjustment in a monetary union, it is often labeled as 'real exchange rate channel' (Roubini et al., 2007) and is expected to be the main compensation for the loss of autonomous monetary policy. Economic adjustment is based here on external competitiveness of an economy, dependent on the real exchange rate:

$$
R E R_{i}=N E R_{i} \cdot \frac{P *}{P_{i}}
$$

To organize the way we think of exchange rates in our analysis, Table 1 summarizes the determinants of various exchange rates at the level of entire union and its member states. Once a monetary union is created, bilateral (or intra-EMU effective) real exchange rates countinue to exist as price level ratios between countries $\left(N E R_{i}=\right.$ const, see last column in Table 1$)$. Every country's REER, idiosyncratically shaped both by trade-weighting and the internal deflator, is influencing a country's output gap by improving or deteriorating a country's external price competitiveness. Although the competitiveness of an economy, as measured by REER vis-a-vis the rest of the world, is determined by all external deflators, external value of the euro, a country's trade composition and domestic price dynamics, competitiveness channel as adjustment mechanism rests on the price level ratio (or, equivalently, log-difference) against other EMU member states. This is why we concentrate on the lower-right cell of Table 1 in this analysis. 
Table 1: Exchange rates in a currency area

\begin{tabular}{|c|c|c|c|c|}
\hline & & $\begin{array}{l}\text { currency area vs } \\
\text { rest of the world }\end{array}$ & $\begin{array}{l}\text { member countries } \\
\text { vs rest of the world }\end{array}$ & $\begin{array}{c}\text { member countries } \\
\text { vs rest of the } \\
\text { currency area }\end{array}$ \\
\hline nominal & bilateral & $\begin{array}{l}\text { common bilateral } \\
\text { nominal rate }\end{array}$ & $\begin{array}{c}\text { common bilateral } \\
\text { nominal rate }\end{array}$ & irrevocably fixed \\
\hline nominal & effective & $\begin{array}{c}\text { common bilateral } \\
\text { nominal rates } \\
\text { aggregate weights }\end{array}$ & $\begin{array}{c}\text { common bilateral } \\
\text { nominal rates } \\
\text { asymmetric weights }\end{array}$ & $\begin{array}{c}\text { irrevocably fixed } \\
- \\
\end{array}$ \\
\hline real & bilateral & $\begin{array}{l}\text { common bilateral } \\
\text { nominal rate } \\
\text { aggregate internal } \\
\text { deflator } \\
\text { common external } \\
\text { deflator }\end{array}$ & $\begin{array}{c}\text { common bilateral } \\
\text { nominal rate } \\
\text { asymmetric internal } \\
\text { deflators } \\
\text { common external } \\
\text { deflator }\end{array}$ & $\begin{array}{c}\text { irrevocably fixed } \\
\text { asymmetric internal } \\
\text { deflators } \\
\text { common external } \\
\text { deflator }\end{array}$ \\
\hline real & effective & $\begin{array}{l}\text { common bilateral } \\
\text { nominal rates } \\
\text { aggregate weights } \\
\text { aggregate internal } \\
\text { deflator } \\
\text { common external } \\
\text { deflator }\end{array}$ & $\begin{array}{c}\text { common bilateral } \\
\text { nominal rates } \\
\text { asymmetric weights } \\
\text { asymmetric internal } \\
\text { deflators } \\
\text { common external } \\
\text { deflators, but } \\
\text { asymmetrically } \\
\text { weighted }\end{array}$ & $\begin{array}{c}\text { irrevocably fixed } \\
\text { asymmetric weights } \\
\text { asymmetric internal } \\
\text { deflators } \\
\text { common external } \\
\text { deflators, but } \\
\text { asymmetrically } \\
\text { weighted }\end{array}$ \\
\hline
\end{tabular}

The key question in the assessment of the real interest rate versus exchange rate interplay is the net effect of both channels over time. Competitiveness channel is commonly considered to dominate the real interest rate channel in the mid- to long term. ${ }^{8}$ Given downward nominal rigidity of prices (and wages), restoring equilibrium via competitiveness channel after a period of overheating may last for a long time and would require below-average inflation rate (Roubini et al., 2007). The literature attributes the smoothness of the adjustment to product and labour market flexibility. Empirical research by European Commission (2006, p. 120) provides some evidence in favour of asymmetry in real exchange rate response to negative and positive output gap. Appreciation of the real exchange rate, when necessary, runs more quickly and a depreciation is much more heterogenous across countries, especially in services (considered a proxy for the non-tradeables sector).

Another dimension that needs to be taken into account when considering the competitiveness channel are productivity developments. Major increases in labour productivity, associated with catching-up and structural reforms, are non-negligible as they offset the negative impact of price dynamics on competitiveness. Ireland is a good example of this: given high productivity dynamics and wage restraint, substantial inflation dynamics over the EMU lifetime did not translate there into substantial losses in competitiveness. For this reason, European Commission (2006) uses unit labour cost dynamics to evaluate trends in competitiveness. In the empirical analysis in this paper, we use the price subindices of goods (overall HICP excluding services).

Is this mechanism a sufficient insurance against a possible destabilization resulting from real interest rates? Again, a few methodological difficulties on the way to the answer can be enumerated: 3.

${ }^{8}$ Empirical research for the United States suggests 3-4 years as a breakpoint (Arnold and Kool, 2004). See section 
Figure 2: Real exchange rate channel

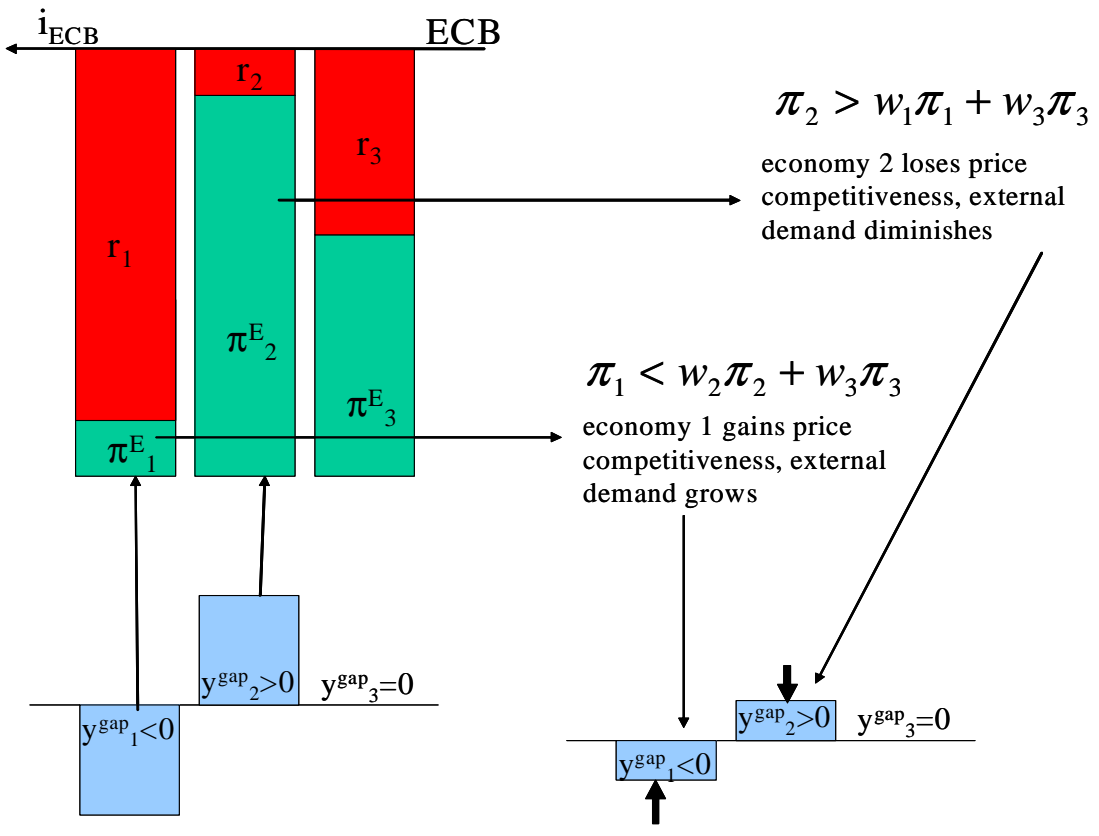

Source: author

1. Asymmetric weights in the trade structures (trade with EMU and non-EMU countries, as in Table 1 and Figure 3b) might imply various degree of effectiveness of this adjustment channel. A country with a low share of EMU countries in foreign trade might be relatively indifferent to real exchange rate dynamics vis-a-vis the rest of the currency area and much more dependent on the external value of the euro. However, rising domestic prices deteriorate competitiveness position of a country against both EMU and non-EMU trade partners.

2. Real interest rate mechanism acts procyclically via internal demand, while real exchange rate channel depends on external demand conditions. Therefore, competitiveness channel could rather be expected to be at work in small economies with a high degree of openness. However, the higher the weight of an economy in a monetary union, the more chance for stabilization from monetary policy.

3. Empirical analysis is additionally complicated by alternative strategies of exporters facing growing ULC: competitive position is deteriorated only when a cycle-related change in production costs is passed on to prices. European Commission (2006, p. 107) notes that exporters either try to maintain their market shares at the cost of reducing their profit margins by pricing to market (the Netherlands, Spain and Portugal named as examples) or attempt at keeping the profit margins unchanged (Italy and Greece mainly in this group).

\subsection{Structural heterogeneity}

Not only do cross-country structural differentials in EMU increase the probability of asymmetric shocks, but they also determine various adjustment patterns once such a shock occurs. This subsection provides an overview of how various characteristics of an economy might influence the pace of coming back to the steady state. Stylized facts described here will be accounted for in our model-based simulations as heterogeneity in parameters between monetary union member countries.

Trivially, differences in a country size ( $w_{j}$ for country $j$ in the model, see section 4 ) could be a source of differences in the adjustment speed. Hoeller et al. (2004) show that large countries are 
less capable of a smooth market-based adjustment than small ones. This is due to the fact that internal demand plays a dominant role and the degree of openness is generally smaller. In our framework, this implies a higher $\beta_{r, j} / \beta_{c, j}$ ratio if country $j$ is large. Moreover, Marzinotto (2007) emphasizes that agents in small open economies normally discount in expectations competitiveness losses resulting from excessive wage and price growth, as they have highly depended on external demand long before a monetary union was created (high $\beta_{c, j}$ ). On the other hand, a high country weight results in a stronger response of the common monetary policy.

Secondly, the key issue in country adjustment dynamics is price (wage) flexibility in the product (labour) market. In our framework, this aspect of heterogeneity is captured in the $\lambda_{j}$ parameters reflecting inflation responsiveness to cyclical conditions. Switching to deep parameters as in Galí and Gertler (1999), it depends on the Calvo (1983) parameter of market rigidities. OECD's product market regulation (PMR) indicators provide some further descriptive evidence of the distortions in price response to shocks. Price adjustments also depend on the input cost (especially wage) flexibility. Labour market institutions in the euro area are designed mainly on the country level. Campolmi and Faia (2007) describe them as a significant source of inflation differentials in a monetary union. They show that in a country with lower replacement rate, workers face a more expensive 'outside option' and are more willing to accept lower wages; as a result, wage and price volatility is higher at the cost of output and employment volatility in the aftermath of a shock. Also, Andersen (2005) analyzes labour market rigidities (especially with respect to wage formation and contract duration) as a factor increasing output volatility, whereby cross-country heterogeneity leads to asymmetric propagation of symmetric shocks. A number of descriptive evidence on various labour market flexibility aspects can be enumerated, including OECD EPL indicators (OECD, 2004) or summary indicators developed by HM Treasury (2003).

Differences in the monetary transmission mechanism are another factor that determines not only adjustment speed (mainly how strong the real interest rate channel amplifies the cycle), but also lead to asymmetric propagation of common monetary policy impulses. In our framework, a high $\beta_{r, j}$ indicates a strong transmission in country $j$. This source of heterogeneity is mainly associated with different institutional setup of the financial markets. Hoeller and Rae (2007), van den Noord (2004), Deroose et al. (2004) and Hoeller et al. (2004) discuss in detail the role of housing market as a critical element in the monetary transmission mechanism. Authors point to differences in the home-ownership rates, taxation, supply constraints and countries' immunity to asset price bubbles as sources of differences in interest rate transmission to the real economy.

Finally, Lane (2006), Deroose et al. (2004) stress the importance of non-EMU trade openness as a possible source of asymmetric developments, as external value of the euro might evolve in a way that a national currency would not have. In the Figure 3, the degree of openness (right panel) and the share of intra-EMU trade (left panel) are presented. A more open economy with a lower share of EMU-trade is relatively more exposed to shocks associated with external value of the euro (see asymmetries associated with REER weighting as indicated in Table 1). Competitiveness channel within the monetary union, in turn, is expected to be more efficient with high trade integration of the member countries, being a combination of both a high degree of openness and a high share of trade volume with EMU partners. In terms of our model, this results in high output vulnerability to real exchange rate divergencies $\left(\beta_{c}\right)$ and high responsiveness of the output gap to other countries' cyclical position $\left(\beta_{s}\right)$, increasing business cycle synchronisation and the probability of common monetary policy response. 


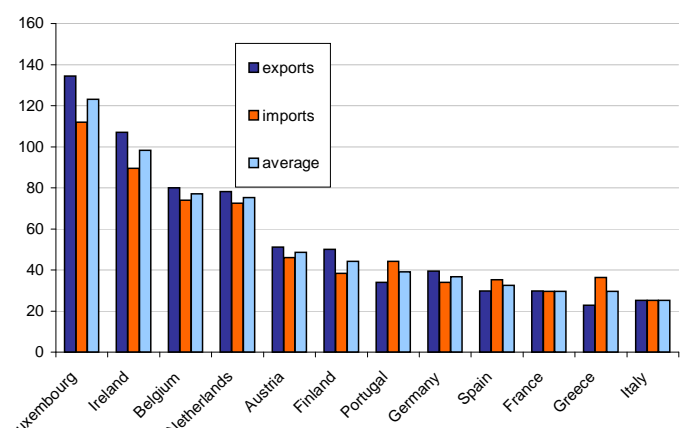

(a) degree of openness (share of exports, imports and average of them in a country's GDP, average 1996-2007)

Source: OECD ICTS and Eurostat

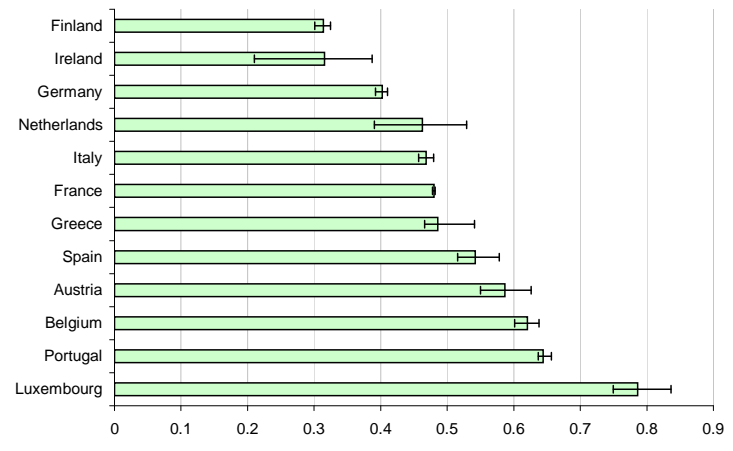

(b) share of intra-EMU trade (exports+imports) in a country's total external trade (error bars represent the share calculated using exports or imports only); 1998-2006 average

Real convergence issues must not be skipped when using various indicators of price developments to assess shifts in price competitiveness between countries. In the catching-up economies, BalassaSamuelson effect leads to higher inflation in the non-tradables because of productivity growth differences between sectors (European Commission, 2006), which implies real exchange rate appreciation. However, this does not necessarily translate into losses in competitiveness in the catchingup economies, as long as the rate of real exchange rate appreciation does not exceed the equilibrium one. This is why inflation target differentials with respect to the EMU-wide inflation target, $\pi_{j}^{*}$, do not induce relative shifts in competitiveness in our model (we see them as continuous shifts in equilibrium). Also, catching-up economies can be expected to exhibit higher natural rates of interest, $r_{j}^{*}$, as marginal productivity of capital stays below the level typical for more advanced economies.

\section{Empirical findings}

Since the launch of the EMU, the subject of adjustment to asymmetric shocks has inspired a lot of empirical research. Table 2 summarizes the findings of Langedijk and Roeger (2007) and the European Commission (2008) who attempt to identify the main sources of macroeconomic variable dynamics in selected EMU countries. The shocks can be grouped into demand and supply disturbances, as well as shocks associated with EMU entry. Langedijk and Roeger (2007) stress the importance of these entry shocks for explaining a large proportion of volatility in main economic variables in the first decade of the euro area.

Synthetic empirical findings on both discussed mechanisms remain limited. Angeloni and Ehrmann (2004) embody into their model a parameter of inflation persistence and conclude this is the main propagation channel of real interest rate effect. A number of country-oriented studies deal with the problem of this effect in detail, see e.g. Honohan and Leddin (2005) for a discussion of real interest rate effect in Ireland or Lopez-Salido et al. (2005) for an analysis of the Spanish case. Roubini et al. (2007) suggest that such procyclical effects could have taken place in Spain, Portugal, the Netherlands, Greece and possibly Italy. Evidence from a panel analysis by Remsperger and Hofmann (2005), however, discards a significant magnitude of real interest rate disequilibrating force, even in the short run, confirming the existence of real exchange rate equilibrating mechanism. Hoeller et al. (2002) simulate the effect of real interest and competitiveness channels with the Irish submodel of OECD's Interlink, concluding the prevalence of the real exchange rate channel in the long run. 
Table 2: Asymmetric shocks in selected countries of EMU, 1999-2008

\begin{tabular}{|l|l|}
\hline Shock & Country example \\
\hline \hline disappearance of risk premium & $\begin{array}{l}\text { Spain }(+), \text { Portugal }(+), \text { Ireland }(+), \text { Italy } \\
(+), \text { Germany }(-), \text { Netherlands }(-)\end{array}$ \\
\hline $\begin{array}{l}\text { liberalization of credit constraints for } \\
\text { households }\end{array}$ & Netherlands $(+)$ \\
\hline $\begin{array}{l}\text { EMU entrance with non-equilibrium nominal } \\
\text { exchange rate }\end{array}$ & Germany $(+)$ \\
\hline TFP shocks in tradables & Ireland $(+)$, Italy $(-)$ \\
\hline TFP shocks in non-tradables & $\begin{array}{l}\text { Ireland }(+), \text { Germany }(+), \text { Italy }(-), \text { Spain } \\
(-), \text { Portugal }(-)\end{array}$ \\
\hline migration and demographic shocks & Spain $(+)$, Ireland $(+)$, Italy $(-)$ \\
\hline wage shocks & Ireland (-), Portugal $(+)$ \\
\hline fiscal policy shocks & Ireland (+), Italy (-), Netherlands $(+)$ \\
\hline shifts in demand & Spain $(-)$, Portugal $(-)$, Italy $(-)$ \\
\hline
\end{tabular}

Source: based on Langedijk and Roeger (2007), European Commission (2008)

Deroose et al. (2004) consider price and wage rigidities to be the main determinant of the speed of adjustment in a monetary union. They emphasize the role inflation persistence and centralisation of wage bargaining in this process. Using a small open economy model with calibrated parameters to simulate adjustment of a 'typical' EMU member economy to an asymmetric demand and competitiveness shock, the authors conclude with a number of policy implications to smooth the adjustment process: structural reforms promoting labour and product market flexibility, promoting further trade and financial integration (to support the market-based competitiveness channel against the real interest rate mechanism), wage moderation policies and automatic fiscal stabilizers.

In a paper by Arnold and Kool (2004), regional adjustment and regional heterogeneity in monetary policy transmission in the United States of America (considered as a monetary union) is analyzed. The authors find evidence in support of the existence of real interest rate's destabilizing effects due to regional inflation differentials. They also arrive at an interesting quantitative conclusion that the real interest rate effect outweighs the real exchange rate channel within 3-4 years and, after that, the negative consequences of competitiveness losses dominate.

\section{The model}

We apply a basic New Keynesian model, stylized to encompass the main features of macroeconomic adjustment in a heterogenous monetary union after different kinds of shocks. We consider asymmetric shocks in only one or a subset of countries and asymmetric transmission of common monetary policy response. The main idea behind the model's specification is to expose and replicate the heterogeneity in macroeconomic developments under single monetary policy, operating on the aggregate level. Our framework in an extension to a standard New Keynesian specification considered i.a. by Lindé (2005) with 3 equations for output gap (hybrid IS curve), inflation (hybrid Phillips curve) and nominal interest rate (Taylor rule). Follwing Clausen and Hayo (2006), we allow, however, for separate IS and Phillips curves for every country ${ }^{9}$ that allow here for divergent paths of output gap and inflation due to asymmetric shocks as well as heterogeneity. Also, open economy extensions are introduced to encompass the real exchange rate channel in the model.

\subsection{Aggregate layer - monetary policy reactions}

The nominal interest rate is set on the aggregate level, basing on the macroeconomic performance of entire euro area (union-wide output gap $y_{t}$ and inflation $\pi_{t}$ ). We use a simple Taylor (1993) rule

\footnotetext{
${ }^{9}$ The Authors estimate a 9-equation system with 3 IS curves, Phillips curves and Taylor rules for Germany, France and Italy in the pre-EMU period.
} 
with smoothing to approximate the ECB decisions ${ }^{10}$ :

$$
i_{t}=(1-\rho)\left(r^{*}+\pi^{*}+\gamma_{\pi}\left(\pi_{t}-\pi^{*}\right)+\gamma_{y} y_{t}\right)+\rho i_{t-1}
$$

$\rho$ is a smoothing parameter of the ECB, $\gamma_{\pi}$ and $\gamma_{y}$ - relative weights attributed to current inflation and output gap respectively, $r^{*}$ - the natural rate of interest for the aggregate euro area and $\pi^{*}$ the inflation target of the ECB. We assume the natural interest rate and the inflation target to be invariant over time.

\subsection{Aggregating identities - input for monetary policy decisions}

Union-wide output gap $\left(y_{t}\right)$ and inflation $\left(\pi_{t}\right)$ are aggregated over member countries $\left(y_{j, t}, \pi_{j, t}\right)$ according to the vector of weights reported by the ECB:

$$
\begin{aligned}
\pi_{t} & =\sum_{j} w_{j} \pi_{j, t} \\
y_{t} & =\sum_{j} w_{j} y_{j, t}
\end{aligned}
$$

We apply constant weights $\left(w_{j}\right)$ for these identities. This is not exactly the case in reality: Eurostat reports a set of country weights every year and they slightly evolve over time, with more major changes occuring only at moments new entries in the euro area (Greece in 2001, Slovenia in 2007). In the calculation of weighted averages for the estimation, we use average country weights over 2001-2006. Although this does not seem to be a really constraining assumption, we should bear it in mind when interpreting the results of the analysis for particular countries. In the long run, shifts in weights could be substantial. It needs to be stressed here that this weighting scheme, associated with official euro-area accounting, assumes no national focus of the decision makers at the $\mathrm{ECB}^{11}$.

\subsection{Country layer - output gap and inflation}

\subsubsection{Country equations}

Our model remains in line with New Keynesian literature on empirical modelling of IS and Phillips curves, including Galí and Gertler (1999), Goodhart and Hofmann (2005) or Lindé (2005).

Following Galí and Gertler (1999) ${ }^{12}$, we prefer a hybrid version of the Phillips curve, including both lagged and rationally expected inflation rate. In our estimation and simulations, we restrict the parameters of past and expected inflation to sum to unity. This allows our steady state to replicate from period to period in the absence of shocks.

$$
\pi_{j, t}=\omega_{f, j} E_{t} \pi_{j, t+1}+\omega_{b, j} \pi_{j, t-1}+\gamma y_{j, t}+\varepsilon_{\pi, j, t}
$$

An autocorrelation in the error term is allowed, naturally present by construction in models with rational expectations. ${ }^{13}$

\footnotetext{
${ }^{10}$ For an extensive set of Taylor rule estimates for the ECB, see e.g. Sauer and Sturm (2003).

${ }^{11}$ For a discussion of alternative institutional setup with rotation in the Governing Council and national bias in decisions, based on the same model, see Kosior et al. (2008).

${ }^{12}$ The only exception being that we replace real marginal cost, that Galí and Gertler (1999) apply, with the current level of the output gap.

${ }^{13}$ Assuming that the difference between expectations and the true value is white noise, $\pi_{t+1}=E_{t} \pi_{t+1}+u_{t+1}$, we conclude with an error term of the form $\varepsilon_{\pi, t}-\omega_{f} u_{t+1}$.
} 


$$
\varepsilon_{\pi, j, t}=\rho_{\pi, j} \varepsilon_{\pi, j, t-1}+\eta_{\pi, j, t}
$$

Our output gap equation for country $j$ resembles the standard hybrid specification considered by Goodhart and Hofmann (2005), including expected future and lagged output gap, as well as the difference between current country-specific ex ante real interest rate $\left(i_{t}-E_{t} \pi_{j, t+1}\right)$ and the natural interest rate $\left(r_{j}^{*}\right)$.

$$
\begin{aligned}
y_{j, t}= & \beta_{f, j} E_{t} y_{j, t+1}+\beta_{b, j} y_{j, t-1}-\beta_{r, j}\left(i_{t}-E_{t} \pi_{j, t+1}-r_{j}^{*}\right)+ \\
& -\beta_{c, j}\left(P_{j, t}-P_{-j, t}-t \cdot 0.25 \cdot\left(\pi_{j}^{*}-\pi_{-j}^{*}\right)-\theta_{j}^{*}\right)-\beta_{s} y_{-j, t}+\varepsilon_{y, j, t}
\end{aligned}
$$

On top of that, two additional regressors are included to account for the openness to other monetary union's economies. They are necessary to replicate properly the features of EMU macroeconomic adjustment and remain in line with the main logic of New-Keynesian open economy framework, as Clarida et al. (2001) state that small country's output gap depends on external demand, as well as prices of domestic goods in foreign currency. ${ }^{14}$

Firstly, the output gap in the rest of the union $\left(y_{-j, t}\right)$, controls for external demand in a highly trade-integrated environment. Secondly, the competitiveness term $\left(P_{j, t}-P_{-j, t}\right)$ incorporates the real exchange rate channel into the model, lowering the output gap when cumulative price growth in country $j$ is excessive. $P_{j, t}$ stands for a cumulated price growth since entering the monetary union and evolves according to the following:

$$
P_{j, t}=P_{j, t-1}+0.25 \cdot \pi_{j, t}
$$

$P_{-j, t}$ denotes the foreign (to country $j$ ) counterpart of $P_{j, t}$, calculated as a weighted average over the rest of the countries ${ }^{15}$ :

$$
P_{-j, t}=\frac{\sum_{k, k \neq j} w_{k} P_{k, t-1}}{\sum_{k, k \neq j} w_{k}}+\frac{\sum_{k, k \neq j} w_{k} \cdot 0.25 \cdot \pi_{k, t}}{\sum_{k, k \neq j} w_{k}}
$$

Two modifications need to be applied to this term in the IS curve. A one-off relative price level adjustment in country $j\left(\theta_{j}^{*}\right)$ is required. Real appreciation or depreciation is necessary to correct for the heterogeneity of $r_{j}^{*}$ and $\pi_{j}^{*}$ with homogenous $i$ in the union's steady state. This counterbalances the steady-state effect of real interest rates heterogeneity, as described in subsection 2.1:

$$
\theta_{j}^{*}=\Delta P_{j}^{*}-\Delta P_{-j}^{*}
$$

However, a change in relative prices does not always affect the competitiveness of a country. Indeed, the real convergence between member states of the currency union requires - through the Balassa-Samuelson effect - real appreciation (or depreciation) of the exchange rate as a part of the equilibrium process in a relatively less (more) developed economy. Distinct equilibrium paths of relative prices are reflected in the differences between implicit inflation targets of currency union member states $\left(\pi_{j}^{*}\right)$. We account for this fact in simulations by assuming that a quarterly price growth consistent with the annualized real exchange rate appreciation (or depreciation) of $\left(\pi_{j}^{*}-\pi_{-j}^{*}\right)$ is an equilibrium phenomenon and does not influence the output gap of a country $j$.

Like $P_{-j, t}$, other variables $(y, \pi)$ that are associated with all countries of the monetary union except $j$ are subscripted $-j$ and constructed as weighted average over these countries:

\footnotetext{
${ }^{14}$ However, whereas in the framework of Clarida et al. (2001) the nominal exchange rate plays a critical role in restoring equilibrium, it is no longer valid in the monetary union regime, which is considered in our study.

${ }^{15}$ Price level outside country $j$ is treated as weighted average of other monetary union countries. This is a convenient assumption for the simulations, but we must bear in mind that asymmetric trade composition (see Table 1) might result in particular vulnerability to competitiveness losses against the main trading partners. This subject requires a country-by-country analysis and remains beyond the scope of this paper.
} 


$$
\begin{aligned}
y_{-j, t} & =\frac{\sum_{k, k \neq j} w_{k} y_{k}}{\sum_{k, k \neq j} w_{k}} \\
\pi_{-j, t} & =\frac{\sum_{k, k \neq j} w_{k} \pi_{k}}{\sum_{k, k \neq j} w_{k}}
\end{aligned}
$$

\subsection{Steady state}

The steady state solution to the model replicates from period to period in the absence of shocks. Output gaps are obviously zero and each country's inflation rate is equal to the countr-specific inflation target $\left(\pi_{j}^{*}\right)$. Every country has got its own natural rate of interest $\left(r_{j}^{*}\right)$ and we know pairwise differences between countries' own inflation targets (deviating from the ECB target of $2 \%$ due to Balassa-Samuelson effect).

Given the values of $\pi_{j}^{*}-\pi_{1}^{*}$ for countries $2,3, \ldots, 12$ and $\pi^{*}$ as inflation target for the entire monetary union, we simply solve for $\pi_{j}^{*}$ for every country.

$$
\boldsymbol{\pi}^{*}=\left[\begin{array}{c}
\pi_{1}^{*} \\
\pi_{2}^{*} \\
\vdots \\
\pi_{12}^{*}
\end{array}\right]=\left[\begin{array}{ccccc}
-1 & 1 & 0 & \ldots & 0 \\
-1 & 0 & 1 & \ldots & 0 \\
\vdots & \vdots & \vdots & \ddots & \vdots \\
-1 & 0 & 0 & \ldots & 1 \\
w_{1} & w_{2} & w_{3} & \ldots & w_{12}
\end{array}\right]^{-1}\left[\begin{array}{c}
\pi_{2}^{*}-\pi_{1}^{*} \\
\pi_{3}^{*}-\pi_{1}^{*} \\
\vdots \\
\pi_{12}^{*}-\pi_{1}^{*} \\
\pi^{*}
\end{array}\right]
$$

Taking additionally $r_{j}^{*}$ for $\mathrm{n}$ countries, we solve for equilibrium value of $i^{*}$ for the whole union and countries' one-off equilibrium price level adjustments, as in (11): ${ }^{16}$

$$
\begin{aligned}
& {\left[\begin{array}{c}
i^{*} \\
\Delta P_{1}^{*}-\Delta P_{-1}^{*} \\
\Delta P_{2}^{*}-\Delta P_{-2}^{*} \\
\ldots \\
\Delta P_{12}^{*}-\Delta P_{-12}^{*}
\end{array}\right]=\left[\begin{array}{ccccc}
-\beta_{r, 1} & -\beta_{c, 1} & 0 & \ldots & 0 \\
-\beta_{r, 2} & 0 & -\beta_{c, 2} & \ldots & 0 \\
\vdots & \vdots & \vdots & \ddots & \vdots \\
-\beta_{r, 12} & 0 & 0 & \ldots & -\beta_{c, 12} \\
0 & w_{1}\left(1-w_{1}\right) & w_{2}\left(1-w_{2}\right) & \ldots & w_{12}\left(1-w_{12}\right)
\end{array}\right] . } \\
& \cdot\left[\begin{array}{c}
-\beta_{r, 1}\left(\pi_{1}^{*}+r_{1}^{*}\right) \\
-\beta_{r, 2}\left(\pi_{2}^{*}+r_{2}^{*}\right) \\
\vdots \\
-\beta_{r, 3}\left(\pi_{12}^{*}+r_{12}^{*}\right) \\
0
\end{array}\right]
\end{aligned}
$$

One of the price levels must be assumed. With differentiated natural rates of interest and inflation targets, price level differences between countries are necessary for the system to remain stable on the country level. Enforcing equal prices across countries in this situation is unstable, as real interest rate mechanism begins to work and shifts price levels apart to their steady state deviations.

\footnotetext{
${ }^{16}$ The first 12 equations are based on IS curves with equilibrium values. The last one reflects the arithmetical fact that the (weighted) sum of deviations from the (weighted) average is zero. Knowing that $P_{-j}^{*}=\frac{\sum_{k, k \neq j} w_{k} P_{k}^{*}}{\sum_{k, k \neq j} w_{k}}=$ $\frac{\sum_{k, k \neq j} w_{k} P_{k}^{*}}{1-w_{j}}$, we can write $P_{j}^{*}-P_{-j}^{*}=P_{j}^{*}-\frac{\sum_{k, k \neq j} w_{k} P_{k}^{*}}{1-w_{j}}$. Multiplying this by $1-w_{j}$ yields $P_{j}^{*}-\sum_{j} w_{j} P_{j}^{*}$, which is deviation of $P_{j}^{*}$ from weighted average over $j$. Weighted sum of these deviations equals zero.
} 


\subsection{Solution of the RE model}

To solve the model with rational expectations, we apply an algorithm proposed by Söderlind (1999). We write the model as

$$
A_{0}\left[\begin{array}{c}
x_{1, t+1} \\
E_{t} x_{2, t+1}
\end{array}\right]=A_{1}\left[\begin{array}{l}
x_{1, t} \\
x_{2, t}
\end{array}\right]-B F\left[\begin{array}{c}
x_{1, t} \\
x_{2, t}
\end{array}\right]+\left[\begin{array}{c}
\eta_{t+1} \\
0
\end{array}\right]
$$

and use matrix $A=A_{0}^{-1}\left(A_{1}-B F\right)$ as an input into the procedure, based on Schur decomposition. Technical details are provided in Appendix A.

\section{Empirical results}

An empirical assessment of the true heterogeneity in parameters discussed in sections 2.3 and 4 is difficult, above all due to short time series. 10 years of EMU experience provided us with about one business cycle, but 40 quarterly observations are rather insufficient for methods that require large samples. This is why the results need to be treated with prudence, as not all the parameters are significantly different from zero.

\section{$5.1 \quad$ Data}

Output gap data is taken from the OECD database, as percentage deviation from the potential production. Because this series is annual, we perform the following interpolation: we use this data to calculate potential output for each country (from annual GDP reported by Eurostat), then interpolate it into quarterly potential output in a linear way. ${ }^{17}$ Quarterly output gap is finally calculated as percentage deviation of quarterly (Eurostat's) real GDP from the potential interpolated value.

As country price indices, we use ECB's data on HICP (which allows to compare consumer prices both across countries and in time). We select this price index also as the ECB target (because our model contains only one price index for every country). However, we do not base our estimations of IS curves on log-difference of HICP indices in a country and in the rest of the euro area due to well-known issues of productivity differentials between sectors and Balassa-Samuelson effect. Instead, we use terms-of-trade calculated as log-difference of HICP goods subindices of a country and abroad, considered as a proxy for price dynamics in the tradable sector. In the simulations, we use the IS curve specification from (8) with constant linear appreciation (or depreciation) in real exchange rate. This approach is equivalent to the one adopted in estimation under the assumption that exogenous productivity differential between both sectors is constant over time and translates into constant relative price growth in one country that does not induce shifts in its external price competitiveness.

As nominal interest rates, we use 3-month money market rate series for the euro area reported by Eurostat. We also use Eurostat's nominal wage index (wages and salaries), real unit labour cost index, nominal effective exchange rates and real GDP volume index, as well as ECB's oil price index (EUR) to include in the instrument sets.

\subsection{Parameter estimates}

In order to take empirical insight in the adjustment process inside the currency union, we estimate the parameters of the system described in section 4. Models with rational expectations are commonly estimated by means of generalized method of moments (GMM), applied in the seminal

\footnotetext{
${ }^{17}$ Quarterly values equal: $Q_{1}(C)=\frac{6}{16} P+\frac{10}{16} C, Q_{2}(C)=\frac{3}{16} P+\frac{12}{16} C+\frac{1}{16} F, Q_{3}(C)=\frac{1}{16} P+\frac{12}{16} C+\frac{3}{16} F$ and $Q_{4}(C)=\frac{10}{16} C+\frac{6}{16} F$ with $\mathrm{P}$ - previous year's, C - current year's and F - following year's annual value.
} 
paper by Galí and Gertler (1999). The assumption that economic agents expect rationally, i.e. do not commit systematic errors conditional on the information set available to them at the moment of prediction, leads to orthogonality conditions for GMM. The "information set" is contained in the instrument matrix. Selecting instruments for each country's IS and Phillips curves, we follow to a large extent Goodhart and Hofmann (2005) in the former and Galí and Gertler (1999) and Rumler (2007) in the latter case and opt for:

- lags of HICP inflation, nominal wage dynamics, oil price growth, nominal effective exchange rate dynamics, real unit labour cost growth and output gap for the Phillips curve;

- lags of output gap, real (ex post) interest rate, real GDP growth, terms of trade, foreign output gap and HICP inflation for the IS curve.

Contrary to existing closed-economy empirical work, we decided to include lagged terms of trade and foreign output gap in the instrument set for the IS curve. We also use nominal effective exchange rate log-change to control for import price dynamics, in the spirit of Rumler (2007) who uses import price to wage ratios. It must be stressed, however, that GMM estimates need to be interpreted carefully. The sample is very short for such an estimation technique (it starts around 1998q1, with slight deviations between countries, and ends in 2008q1) and the conclusions we can draw are mainly qualitative, in the light of sensitivity of output response reported in our simulations. Importantly, due to lack of proper time series, Phillips curves for Greece and Portugal were not instrumented by real ULC growth. Table 3 contains the estimates of model parameters. In none of the cases, the $J$ test rejected the set of overidentifying restrictions.

Table 3: Parameter estimates

\begin{tabular}{|c|c|c|c|c|c|c|c|c|}
\hline & $\beta_{f}$ & $\beta_{\mathrm{r}}$ & $\beta_{c}$ & $\beta_{\mathrm{s}}$ & $\omega_{f}$ & $\gamma$ & $\mathrm{J}$ (is) & $J(p h)$ \\
\hline \multirow{2}{*}{ Austria } & 0,51 & $-0,02$ & 0,03 & 0,05 & 0,56 & 0,10 & 0,15 & 0,22 \\
\hline & 0,00 & 0,20 & 0,00 & 0,00 & 0,00 & 0,00 & 1,00 & 1,00 \\
\hline \multirow[t]{2}{*}{ Belgium } & 0,44 & 0,06 & 0,19 & 0,09 & 0,46 & 0,01 & 0,08 & 0,20 \\
\hline & 0,00 & 0,04 & 0,04 & 0,00 & 0,00 & 0,61 & 1,00 & 1,00 \\
\hline \multirow[t]{2}{*}{ Finland } & 0,76 & 0,19 & 0,02 & 0,13 & 0,91 & 0,06 & 0,16 & 0,26 \\
\hline & 0,00 & 0,07 & 0,04 & 0,00 & 0,05 & 0,00 & 1,00 & 1,00 \\
\hline \multirow[t]{2}{*}{ France } & 0,53 & 0,04 & 0,02 & 0,04 & 0,41 & 0,04 & 0,14 & 0,24 \\
\hline & 0,00 & 0,21 & 0,05 & 0,05 & 0,00 & 0,14 & 1,00 & 1,00 \\
\hline \multirow[t]{2}{*}{ Germany } & 0,61 & $-0,03$ & 0,12 & 0,10 & 0,28 & 0,05 & 0,18 & 0,26 \\
\hline & 0,00 & 0,72 & 0,03 & 0,04 & 0,00 & 0,00 & 1,00 & 1,00 \\
\hline \multirow[t]{2}{*}{ Greece } & 0,47 & $-0,08$ & 0,04 & $-0,08$ & 0,58 & 0,01 & 0,10 & 0,28 \\
\hline & 0,00 & 0,15 & 0,02 & 0,04 & 0,00 & 0,02 & 1,00 & 1,00 \\
\hline \multirow[t]{2}{*}{ Ireland } & 0,47 & 0,90 & 0,58 & 0,03 & 0,36 & 0,00 & 0,14 & 0,34 \\
\hline & 0,00 & 0,01 & 0,00 & 0,82 & 0,00 & 0,05 & 1,00 & 1,00 \\
\hline \multirow[t]{2}{*}{ Italy } & 0,49 & 0,11 & $-0,01$ & 0,08 & 0,44 & 0,10 & 0,17 & 0,26 \\
\hline & 0,00 & 0,00 & 0,88 & 0,05 & 0,00 & 0,00 & 1,00 & 1,00 \\
\hline \multirow[t]{2}{*}{ Luxembourg } & 0,30 & 0,16 & 0,11 & 0,27 & 0,42 & 0,00 & 0,17 & 0,23 \\
\hline & 0,00 & 0,13 & 0,00 & 0,03 & 0,00 & 0,86 & 1,00 & 1,00 \\
\hline \multirow[t]{2}{*}{ Netherlands } & 0,50 & 0,08 & 0,03 & 0,02 & 0,55 & 0,00 & 0,13 & 0,21 \\
\hline & 0,00 & 0,01 & 0,03 & 0,04 & 0,00 & 0,56 & 1,00 & 1,00 \\
\hline \multirow[t]{2}{*}{ Portugal } & 0,49 & $-0,08$ & $-0,01$ & $-0,05$ & 0,52 & $-0,01$ & 0,10 & 0,20 \\
\hline & 0,00 & 0,16 & 0,80 & 0,30 & 0,00 & 0,62 & 1,00 & 1,00 \\
\hline \multirow[t]{2}{*}{ Spain } & 0,56 & 0,05 & $-0,01$ & 0,13 & 0,15 & 0,11 & 0,15 & 0,26 \\
\hline & 0,00 & 0,07 & 0,46 & 0,00 & 0,00 & 0,00 & 1,00 & 1,00 \\
\hline AVERAGE & 0,51 & 0,11 & 0,09 & 0,07 & 0,47 & 0,04 & & \\
\hline MEDIAN & 0,50 & 0,05 & 0,03 & 0,06 & 0,45 & 0,02 & & \\
\hline MEDIAN VALID & 0,50 & 0,10 & 0,04 & 0,09 & 0,45 & 0,06 & & \\
\hline $\begin{array}{l}\text { MEDIAN WITH } \\
\text { INVALID=0 }\end{array}$ & 0,50 & 0,02 & 0,03 & 0,06 & 0,45 & 0,01 & & \\
\hline
\end{tabular}

Yellow fields - insignificant estimates. Red field - significant, but incorrectly signed estimate. Source: author. 
Despite our results remain roughly in line with the existing literature, some deviations from the estimates reported so far can be observed. Forward- and backward looking behaviour in both curves is highly significant and its values are acceptably between 0 and 1 , with (unweighted) average over countries at around 0.5. However, there is some heterogeneity in this respect, especially in the case of forward-looking component in the Phillips curve. Estimates are generally lower in big economies (such as Germany and Spain) and high in Finland. These results are far from Galí and Gertler (1999) conclusion that forward-looking behaviour dominates in the Phillips curve for the United States or Clarida et al. (2001) estimates for the euro area as a whole. They remain, however, in line with a widespread belief that inflation differentials between euro area countries are highly persistent. The degree of forward-lookingness in the IS curves exhibits less heterogeneity, but Finland remains an outlier on the upside also in this case. For the baseline scenario in the simulations in our model, we use values of 0.5 for $\beta_{f}$ and $\beta_{b}$, as well as 0.55 for $\omega_{f}\left(0.45\right.$ for $\left.\omega_{b}\right)$.

The output gap parameter in the Phillips curve, $\gamma$, turned out to be insignificant (and close to zero) in five cases. Valid estimates range from slightly below 0.01 for Ireland to 0.11 for Spain. Significant price responsiveness to output gap has been recorded in Austria, Germany and Finland countries that experienced competitive real exchange rate depreciation vis-a-vis the rest of the euro area over the last decade, but also in Italy and Spain. Insignificant estimates have been recorded in France, Belgium, Netherlands, Luxembourg and Portugal - a country where reforms aimed at enhancing market flexibility were intensified after 2005 and might not yet be visible enough to yield a significant estimate. Values of $\gamma$ generally confirm that product and labour market flexibility remains a concern in smooth functioning of EMU, as median value of valid estimates equals 0.06 (or 0.01, when we take all estimates into account, but set insignificant ones equal to zero). This is far below 0.13 proposed by Lindé (2005) as a consensus from the literature. Our baseline simulation excercise is based on $\gamma=0.06$, median valid estimate.

Once the relative prices rise or fall, however, the competitiveness channel seems to provide efficient stabilization among euro area countries. In 9 of 12 countries, estimates of $\beta_{c}$ are correctly signed and significant. Output gap is the most strongly influenced by shifts in relative price competitiveness in Belgium, Germany and Luxembourg; insignificant estimates are reported for Italy, Portugal and Spain. Note that efficient stabilization within the competitiveness channel requires that both (i) in an overheated economy, prices react promptly to excess demand $(\lambda)$ and (ii) output gap responds significantly to high price level $\left(\beta_{c}\right)$. In case of our estimates, the only country where both estimates are significant is Germany. In Italy or Spain, where estimates of $\lambda$ were relatively high, the influence of real exchange rate on the output gap was (so far) insufficiently significant. Finally, in Portugal, where adjustment is widely considered to have been a painful and prolongued process, neither of the key estimates was statistically significant. As our baseline value for simulations, we apply $\beta_{c}=0.04$ again as median value over valid estimates.

A more nuanced picture emerges from the estimates of $\beta_{r}$, output gap response to country-specific real interest rate. In half of the countries, including Germany and France, no statistically significant link from interest rate to output gap has been established in the data. On the other hand, countries where high $\beta_{r}$ values were estimated in our excercise, such as Italy, Spain, the Netherlands and Ireland, are among the monetary union members subject to procyclical real interest rate effect, enumerated by Roubini et al. (2007). In spite of well-known problems in the empirical literature on IS curves, the median over valid estimates amounts to 0.10 and remains close to the baseline value of 0.09 proposed by Lindé (2005). A high degree of heterogeneity in $\beta_{r}$ is negative on the one hand, as it implies asymmetric monetary transmission. However, countries with low output gap response to their country-specific real interest rate are less exposed to the real interest rate effect. An additional GMM estimation of the IS curve for the euro area as a whole resulted in $\beta_{r}=0.041$ significant with p-value 0.061 , confirming that this parameter is significant for the entire monetary union at the same time. ${ }^{18}$ From this perspective, limited response on the country level remains good news for the adjustment process on the country level.

Finally, other euro area countries' aggregate output gap has a significant and positive influence on domestic output gap in most of the cases. Incorrect sign for Greece is probably due to very short

\footnotetext{
${ }^{18}$ For the euro area as a whole, $\beta_{f}=0.60$ and $\beta_{c}=0.008$, both significant at the level of 0.01. REER based on CPI against the rest of the world was used as a measure of competitiveness.
} 
time series available (only since 2000), which limits the reliability of these estimates. Insignificant estimate of $\beta_{s}$ for Ireland also does not surprise, given the low share of trade with EMU partners depicted in Figure 3. In most of the other cases, valid $\beta_{s}$ around the median of 0.09 is estimated. A very high estimate of 0.27 in the case of Luxembourg also remains in line with our expectations: in this very small economy, the foreign output gap seems to be the main driver of the domestic one.

To sum up, our empirical findings provide some evidence of both real exchange rate and real interest rate mechanism being effectively at work. In the following sections, we use the values obtained to take a more detailed look at how various aspects of heterogeneity influence an adjustment of an asymmetric shock.

\section{Consequences of heterogeneity - simulation excercise}

\subsection{Asymmetric shocks - baseline scenario}

Before we proceed to analyzing how heterogeneity in parameters affects the adjustment path, we shall take more insight into how both channels considered within our model determine the output gap (and other variables') response to asymmetric shocks in the baseline scenario. Baseline parameter values are not far from the consensus of New-Keynesian literature (see e.g. Lindé, 2005 for a survey-based set of values) and were based on our estimates discussed in Section 5. On top of that, we assume a Talyor rule with a 1.5 to 1 response to inflation's deviation to the ECB target $(2 \%)$ and 0.5 to 1 response to current output gap. Following Lindé (2005), we also allow for autocorrelation of 0.5 in demand shocks. For simplicity of exposition, we consider here a 10country monetary union with country weights 0.1 , focusing on consequences of asymmetric shocks and parameter value deviations in one of them. The set of parameters used in this subsection is summarized in Table 4.

Table 4: Default parameter values

Source: author

\begin{tabular}{|cc|cc|cc|cc|cc|cc|cc|}
\hline$\omega_{f}$ & 0.55 & $\beta_{f}$ & 0.5 & $\beta_{r}$ & 0.09 & $\beta_{c}$ & 0.04 & $\rho_{\pi}$ & 0.0 & $\gamma_{\pi}$ & 1.5 & $\rho$ & 0.5 \\
\hline$\omega_{b}$ & 0.45 & $\beta_{b}$ & 0.5 & $\gamma$ & 0.06 & $\beta_{s}$ & 0.09 & $\rho_{y}$ & 0.5 & $\gamma_{y}$ & 0.5 & $w_{j}$ & 0.1 \\
\hline
\end{tabular}

A surprise increase in output gap in one of the countries (Figure 4a) is immediately followed by a rise in inflation. Agents promptly take into account that the shock is autocorrelated, output gap - intrinsically persistent and output gaps between countries correlate due to trade linkages. After 2-3 quarters, the output gap still exceeds the impact response as growing inflation rate boosts inflation expectations and the real interest rate effect sets in. Cumulative price growth undermines, however, the country's price competitiveness and output gap starts decreasing, closing itself within around 6 quarters. Persistence of inflation and output gap also cause overshooting of output's and inflation's equilibrium levels. Note only very limited response of common monetary policy to this asymmetric shock.

An adverse supply shock, associated here with exogenous surge in inflation, immediately hits the output due to appreciating real exchange rate (see Figure $4 \mathrm{~b}$ ). In a small economy, there is very little central bank reaction. Key adjustment mechanisms are again the real exchange rate channel and agents' forward-looking behaviour. The output gap remains negative until its effect on disinflation is strong enough to improve competitiveness through a country's real depreciation. Note that such adverse supply shocks are particularly dangerous in a small economy without its own monetary policy. 
Figure 4: Baseline simulations - adjustment to asymmetric shocks

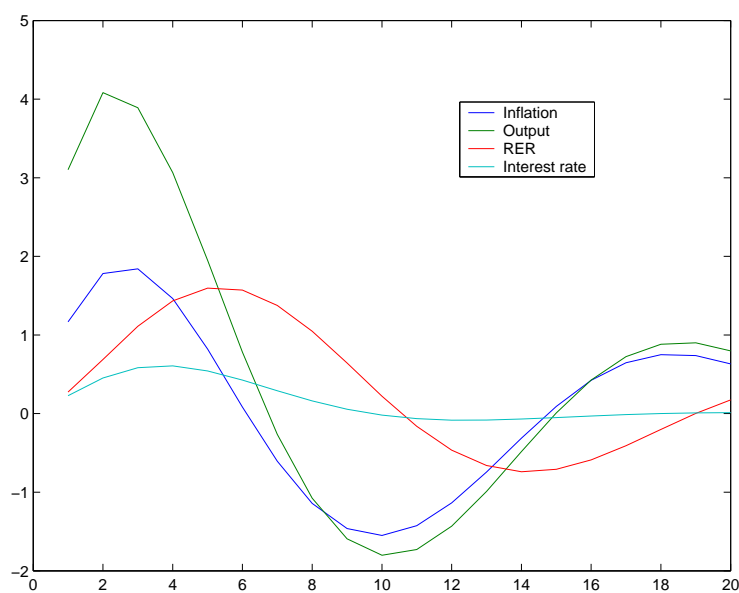

(a) unit demand shock

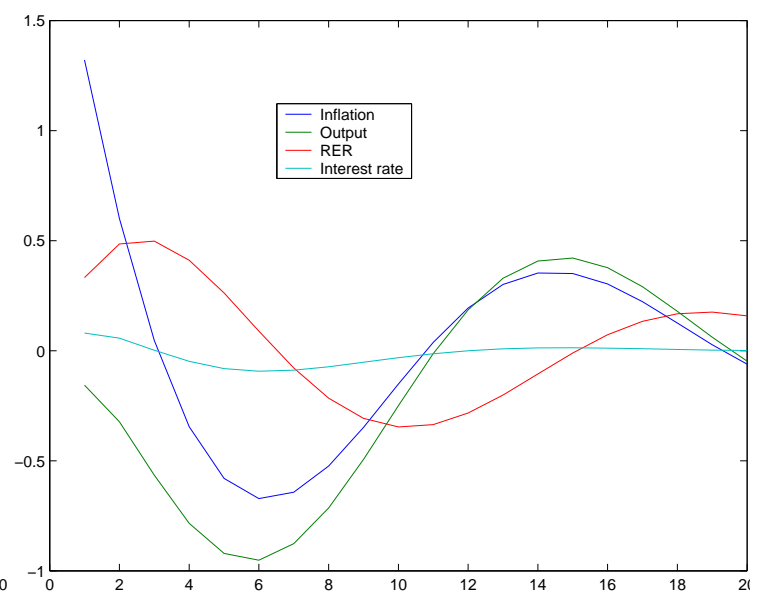

(b) unit supply shock

Source: author

Figure 5: Output adjustment sensitivity to country weights $\left(w_{j}\right)$

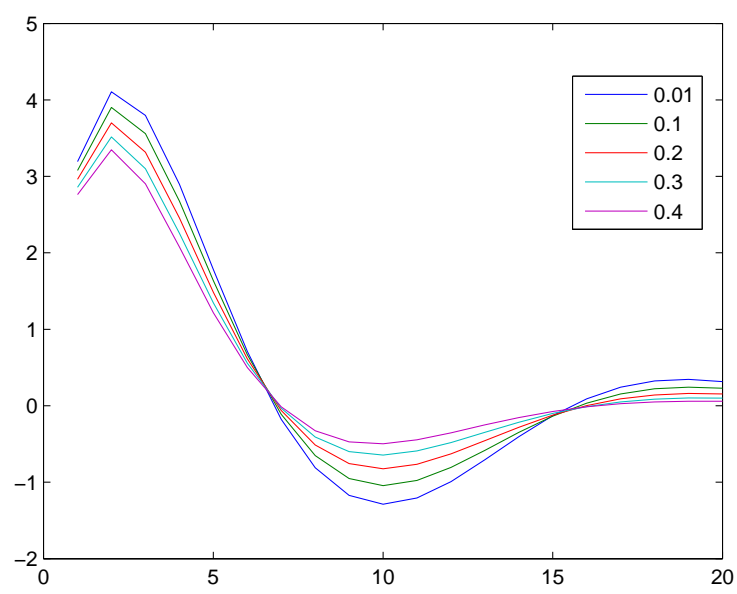

(a) unit demand shock

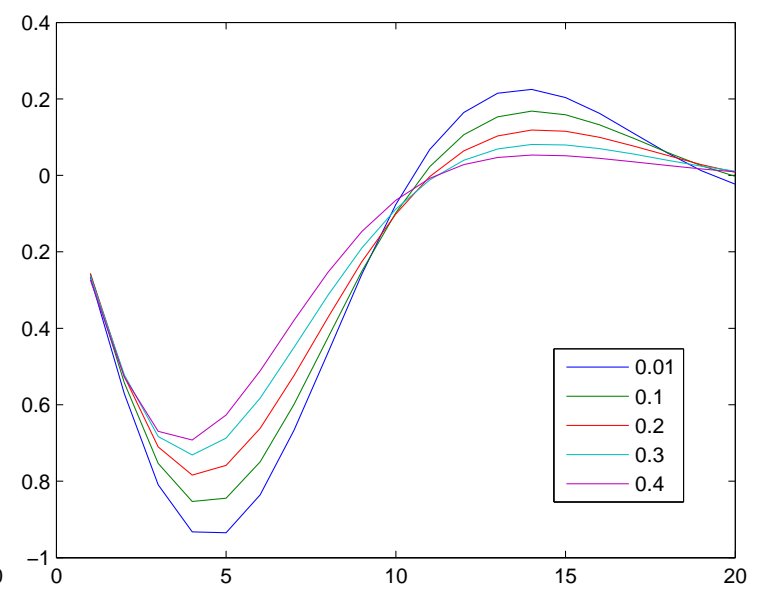

(b) unit demand shock

Source: author

\subsection{How heterogeneity affects adjustment - sensitivity analysis}

In order to take better insight into the determinants of the adjustment speed, we examine the sensitivity of the adjustment path presented in subsection 6.1 to different parameter values in the model. We consider ranges for parameter values observed in our estimates (Table 3) and present in the existing literature. This allows us to disentangle differentials in adjustment capacity of different countries into separate parameter values. We consider for simplicity a monetary union with countries of equal size 0.1 and, unless stated otherwise, we assign baseline parameter values to all countries except the one hit by an asymmetric shock, changing one (or more) of parameters in this economy to examine the sensitivity of adjustment path. Graphs on the left-hand side depict adjustments after demand shocks (to output gap), on the right-hand side - after supply shocks (to inflation).

As expected, amplitude of output gap reaction is somewhat lower when an asymmetric demand shock hits a big country (Figure 5). Although there is obviously difference in reaction between a country participating in a monetary union and staying outside it, the differences in adjustment pattern are not extremely pronounced over the range of country weights in EMU, at least in 
Figure 6: Output adjustment sensitivity to forward-looking behaviour in inflation expectations $\left(\omega_{f}\right.$ in $(6)$ )

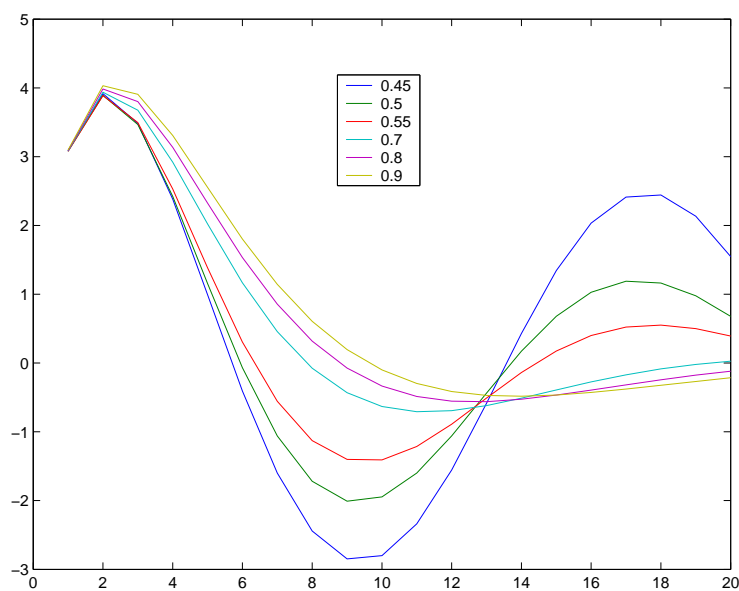

(a) unit demand shock

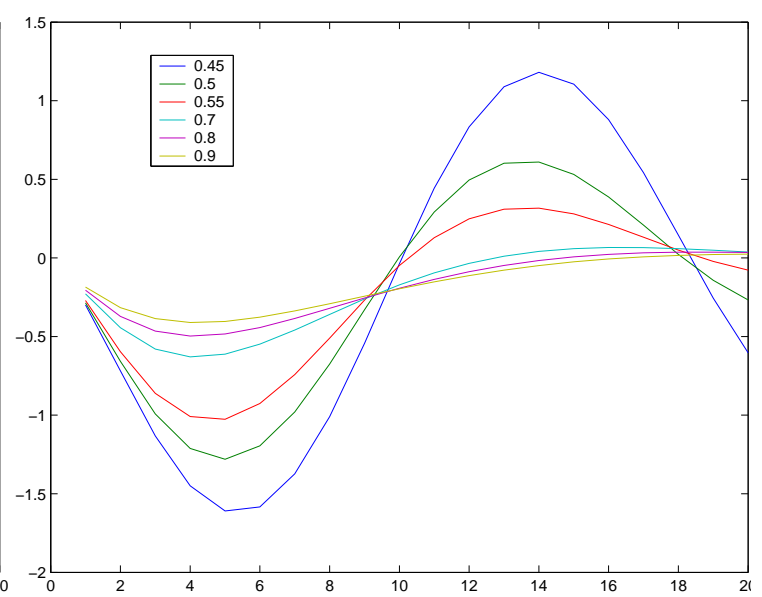

(b) unit supply shock

Source: author

comparison to other aspects of variability. The difference in reactions after a supply shock is even less pronounced (note different scales on both graphs). This confirms that common monetary policy plays a limited role in the adjustment process even if a country is considered big for EMU standards (Germany's weight amounts to approximately 30\%) and casts doubts on results emphasizing big qualitative differences in big and small countries' position under common monetary policy, provided that country weights in this policy really reflect relative sizes of economies in terms of GDP.

Forward-looking behaviour in the Phillips curve seems to be critical for the adjustment process (see Figure 6). The higher is the weight of rational expectations in the Phillips curve (at the cost of lagged inflation), the smoother is the adjustment path. Note that in the initial phase after a demand shock, the difference in inflation persistence does not matter very much; however, when the forwardlooking component is strongly dominating the rule-of-thumb price setting based on past inflation, a unit demand shock is almost smoothed within 8-9 quarters. With strong inflation persistence, the risk of overshooting the equilibrium levels and long boom-bust cycles grows. After a unit supply shock, a period of subdued output growth (output gap slightly less than 0) continues for a few quarters, but the output variability remains very limited when expectations are highly rational. The model is particularly sensitive to the degree of backward-lookingness in the Phillips curve, with intrinsic inflation persistence parameter above 0.6 destabilizing the system. Interestingly, already a value below 0.5 (and absolutely below 0.4 ) ensures smooth adjustment. This is visible both for output and inflation shocks.

The mechanism of forming expectations is fundamental for assessing the risk of procyclical real interest rate effect. In Figure 7, we repeat the simulations from Figure 6 with inflation expectations in the IS curve are partly rational and partly static.

$$
E_{t} \pi_{t+1}=\alpha \cdot E_{t} \pi_{t+1}^{R}+(1-\alpha) \cdot \pi_{t-1}
$$

Rational expectations $E_{t} \pi_{t+1}^{R}$ assume absence of any systematic prediction errors. Note that this additional inclusion of $1-\alpha$ fraction of static expectations will introduce into the IS curve, lagged inflation with coefficient $-\beta_{r}(1-\alpha)$. In simulations presented in Figure 7, both degree of forwardlookingness of the Phillips curve and the composition of inflation expectations in the IS curve (rational versus static) were changed in line $\left(\alpha_{j}=\omega_{f, j}\right)^{19}$. Stabilizing effect of more rational expectations can be observed even more clearly than in Figure 6, when analogous lines are compared.

\footnotetext{
${ }^{19}$ In our GMM estimations and all other simulation exercises, we assume purely rational expectations and do not include lagged inflation into real interest rate term in the IS curve.
} 
Figure 7: Output adjustment sensitivity to rationality of inflation expectations (including IS curve, $\omega_{f}$ in (6) and $\alpha$ in (16))

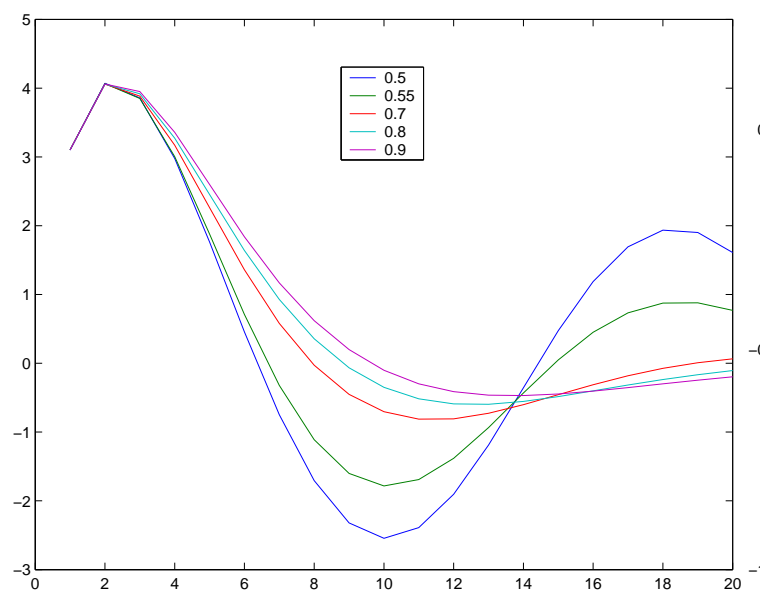

(a) unit demand shock

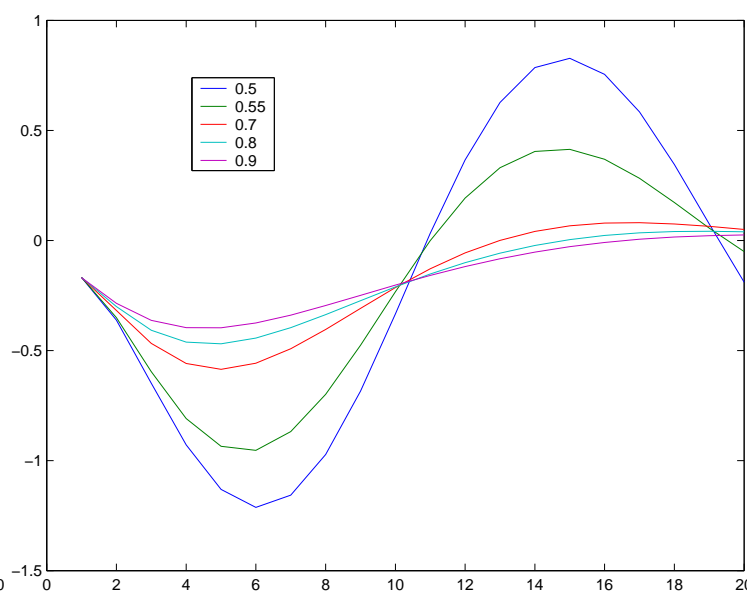

(b) unit supply shock

Source: author

Forward-looking behaviour in the IS curve $\left(\beta_{f}\right.$, Figure 8$)$ is also critical for dampening the variance of output after both demand and supply asymmetric shocks. Note that this is the only case when we register very different responses at impact and in the initial quarters. If the backward-looking behaviour in the IS curve is low enough, the hump-shaped response (partly attributable to real interest rate effect) diminishes and rational agents smooth the shock after only 4-5 quarters. On the contrary, highly persistent output gap boosts the variance and increases the risk of overshooting the equilibrium levels after both types of shocks.

As emphasized before, flexible price reactions is necessary for the competitiveness channel to work. Figure 9 presents the sensitivity of the adjustment process to different values of inflation responsiveness to the output gap. In line with the existing literature, that usually ends up with policy recommendation to promote market flexibility, as our exercise confirms high variance of real variables when product and labour markets are rigid enough to prevent prices from quick adjustment to excess demand. With our median over valid estimates of $\gamma=0.06$, output gap starts falling $3-4$ quarters after a positive demand shock when competitiveness channel outweighs the real interest rate effect. More flexible markets reduce the output gap growth in the first quarters, accelerating the real exchange rate channel's response, but the amplitude and overshooting pattern remain similar. The adjustment to adverse supply shocks is long and painful when the initial loss in competitiveness is not quickly offset by disinflation due to falling output gap. When the markets are rigid, recession needs to be deep in order to induce sufficient real depreciation.

Another exercise associated with flexibility, presented in Figure 10, casts some doubt on HM Treasury (2003) conclusion that relative price flexibility (difference versus the rest of the monetary union) also matters for the adjustment process. The report suggests that a country's advantage in terms of market flexibility over the rest of a monetary union results in a premium for this country. In fact, varying foreign market flexibility (be it less, equal or more than in the domestic economy) does not significantly reshape the domestic adjustment path when an assymetric shock hits the domestic economy as long as domestic $\gamma$ is held constant. This conclusion remains in line with the one by Everaert and Schule (2006), who suggest that there are no positive or negative spillover effects from reforms targeted at improving market flexibility in a single country. What really matters in this model is just the domestic flexibility in absolute terms.

The second element of an effective competitiveness channel in our model, output gap response to cumulative real appreciation or depreciation $\left(\beta_{c}\right)$, plays a critical role in the speed of restoring equilibrium (see Figure 11). Output gap impact responses to an asymmetric demand shock 
Figure 8: Output adjustment sensitivity to forward-looking behaviour in output expectations $\left(\beta_{f}\right.$ in 8)

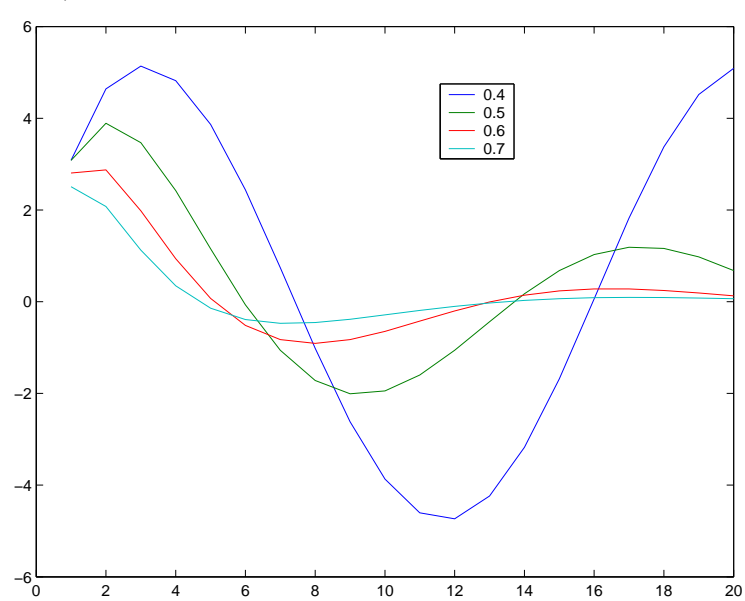

(a) unit demand shock

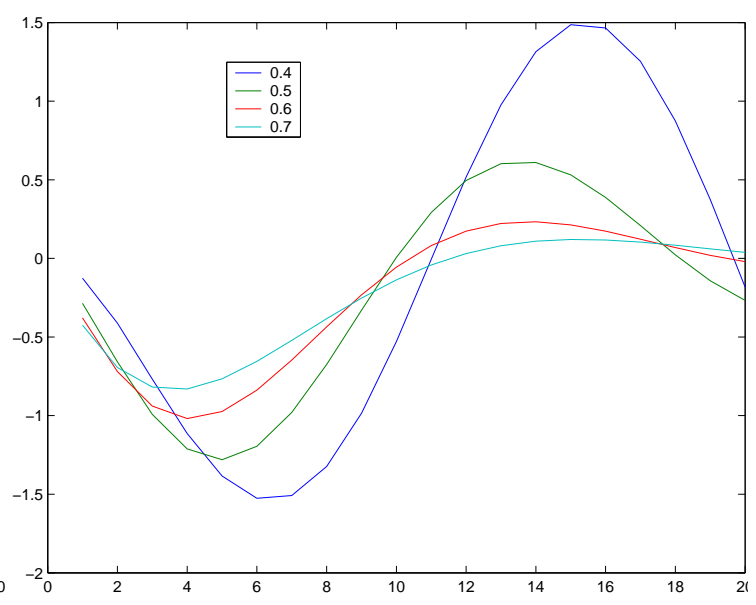

(b) unit supply shock

Source: author

Figure 9: Output adjustment sensitivity to inflation responsiveness to output gap $\left(\gamma_{j}\right.$ in $\left.(6)\right)$

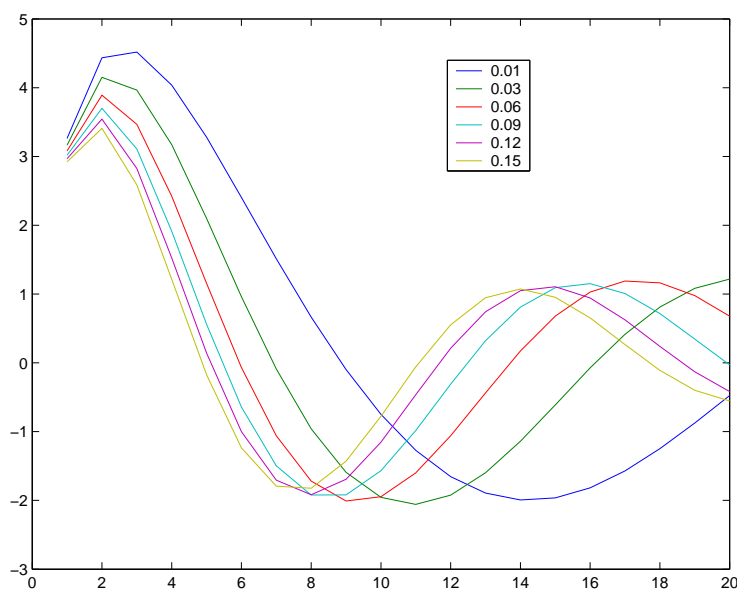

(a) unit demand shock

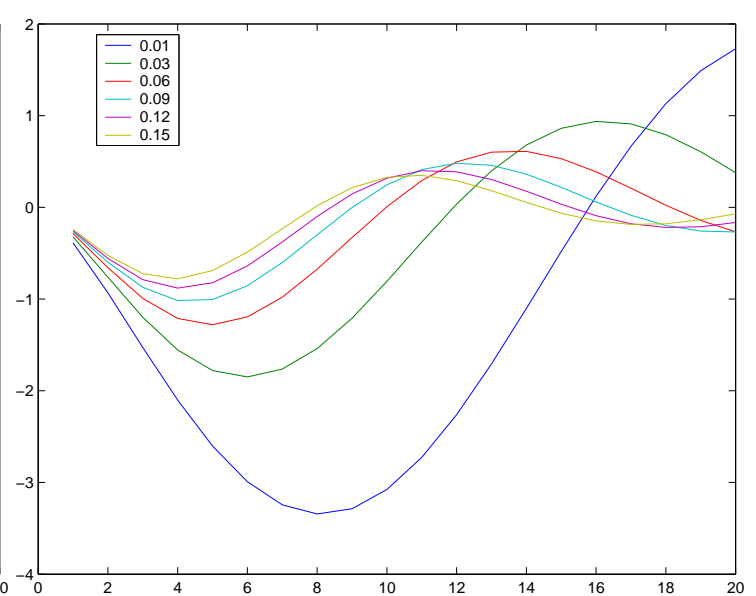

(b) unit supply shock

Source: author 
Figure 10: Output adjustment sensitivity to foreign price flexibility $\left(\gamma_{-j}\right.$ in $\left.(6)\right)$

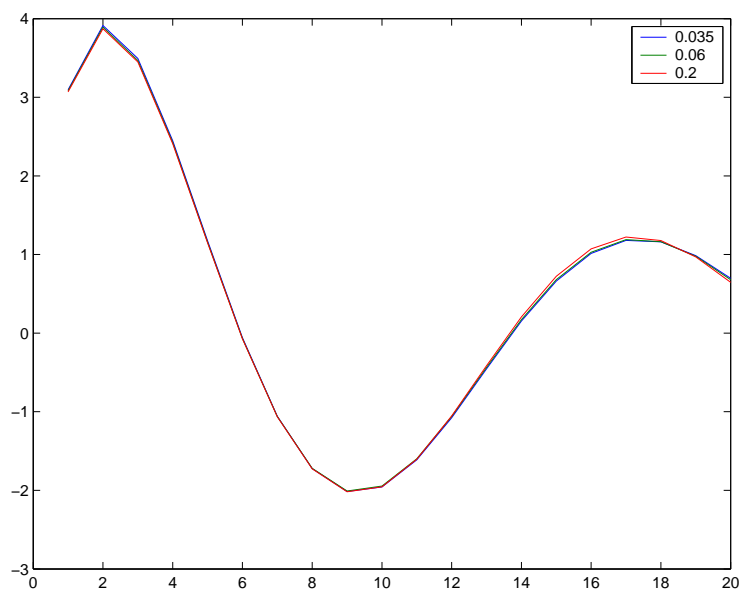

(a) unit demand shock

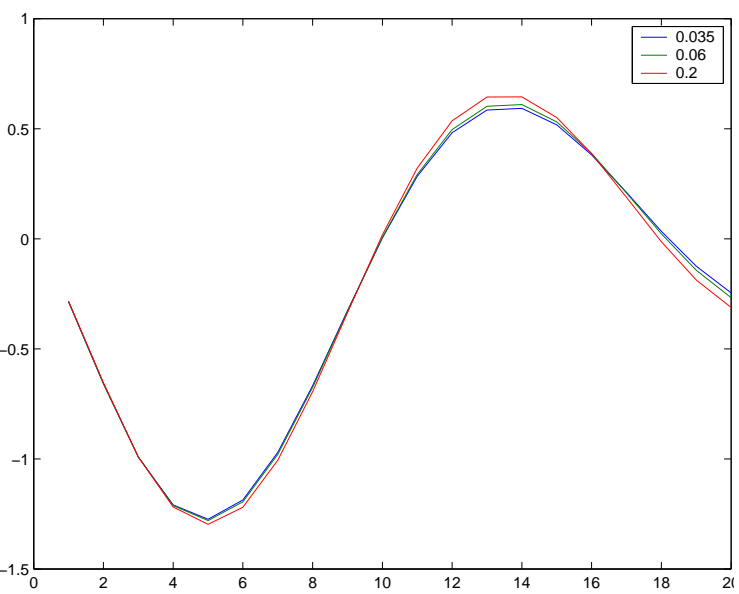

(b) unit supply shock

Source: author

Figure 11: Output adjustment sensitivity to real exchange rate parameter $\left(\beta_{c}\right.$ in (8))

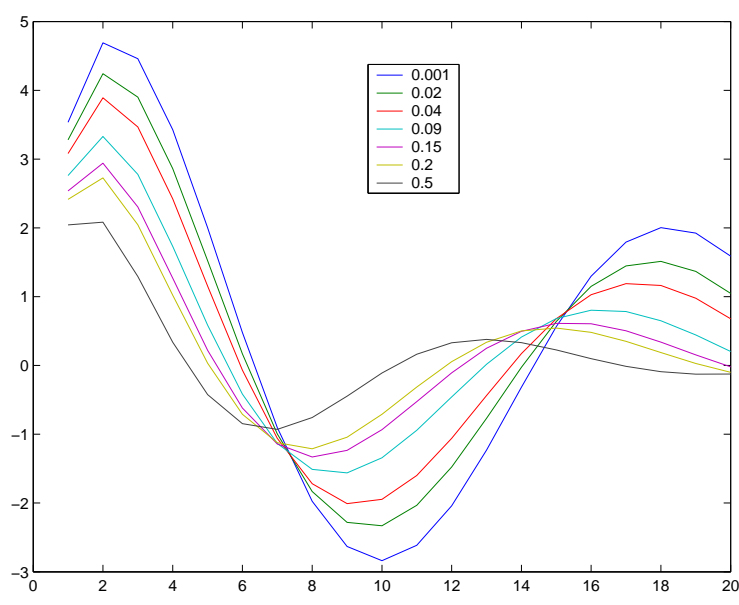

(a) unit demand shock

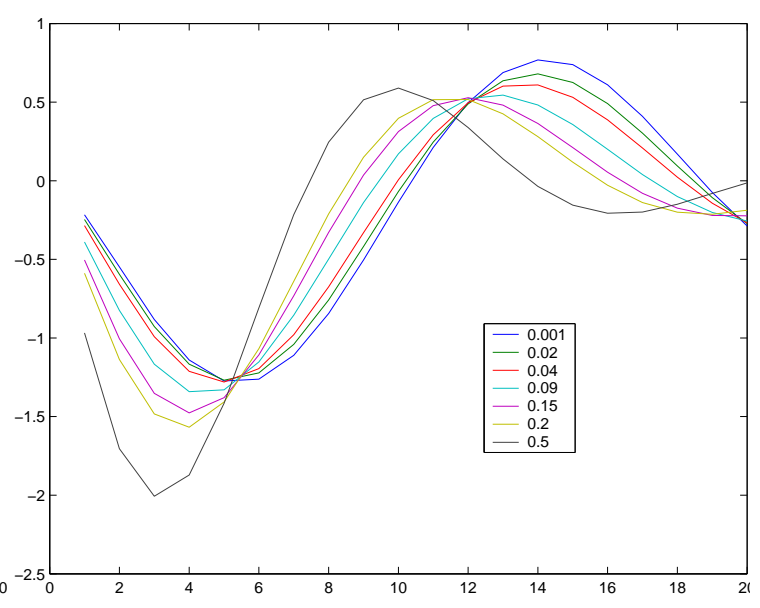

(b) unit supply shock

Source: author 
Figure 12: Competitiveness channel - sensitivity to market flexibility $(\gamma$ in $(6))$ with various $\beta_{c}$ (in (8))

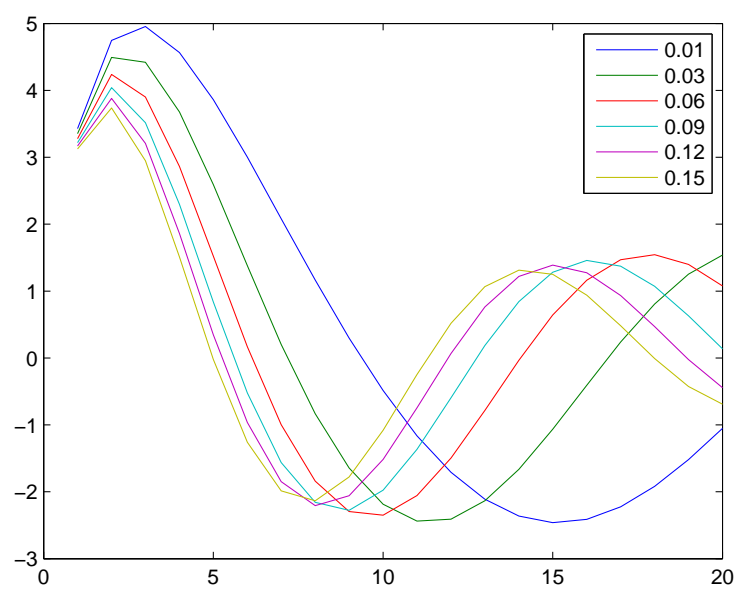

(a) unit output shock

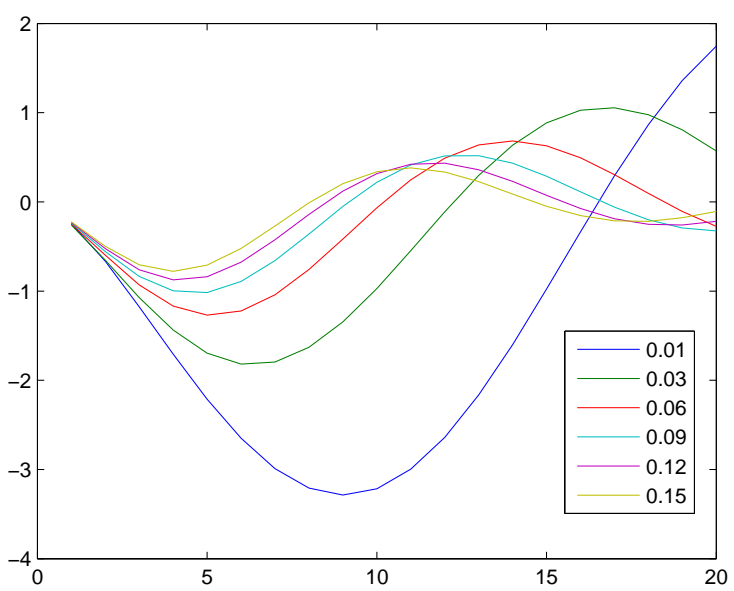

(b) unit output shock

various $\gamma$ and $\beta_{c}=0.02$

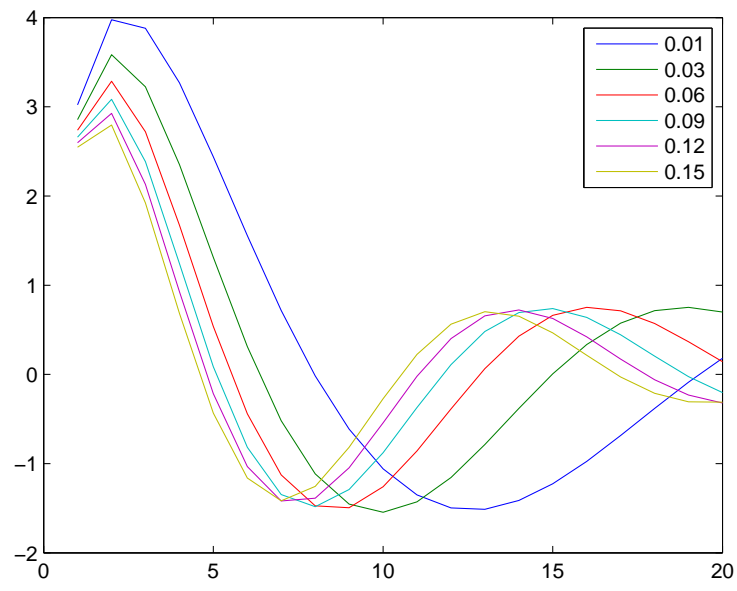

(c) unit output shock

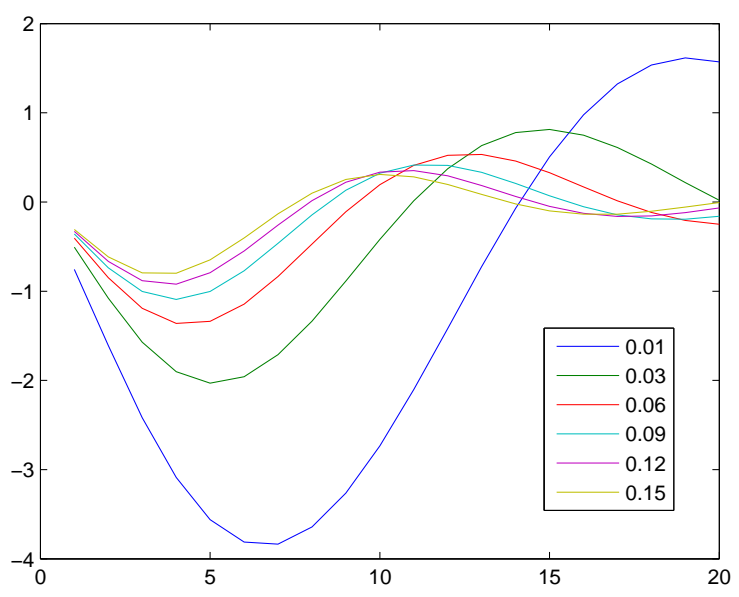

(d) unit output shock

Source: author

various $\gamma$ and $\beta_{c}=0.1$

vary notably, depending on how the demand for the country's production is sensitive to the real appreciation over the empirical range of $\beta_{c}$ from Table 3. This initial dampening of output gap growth, which is able to suppress the real interest rate effect even in the short run, prevents prices from growing faster. As a result, an open and highly trade-integrated economy is very resistant to demand shocks. However, the opposite is the case with supply shocks. When inflation grows exogenously, the output gap is hit particularly strongly in an economy with high $\beta_{c}$. A deep and short recession helps to restore the equilibrium price level and production. Low $\beta_{c}$ reduces the initial response, but the variance in more advanced phases of adjustment remains similar independently on this value.

An optimum combination of both determinants of the competitiveness channel efficiency, $\gamma$ and $\beta_{c}$, depends on the nature of the shock. In Figure 12, adjustment with various combinations of both parameter values is presented. We can see there a qualitative difference between findings for demand and supply shocks. When an asymmetric demand shock hits an economy, the best reaction occurs under high market flexibility and high output gap sensitivity to real exchange rate. In this case, the output gap is less volatile and the shock dies out more quickly. In the case of a supply shock, lower real exchange rate sensitivity of the output gap combined with flexible markets 
Figure 13: Output adjustment sensitivity to real interest rate parameter $\left(\beta_{r}\right.$ in (8))

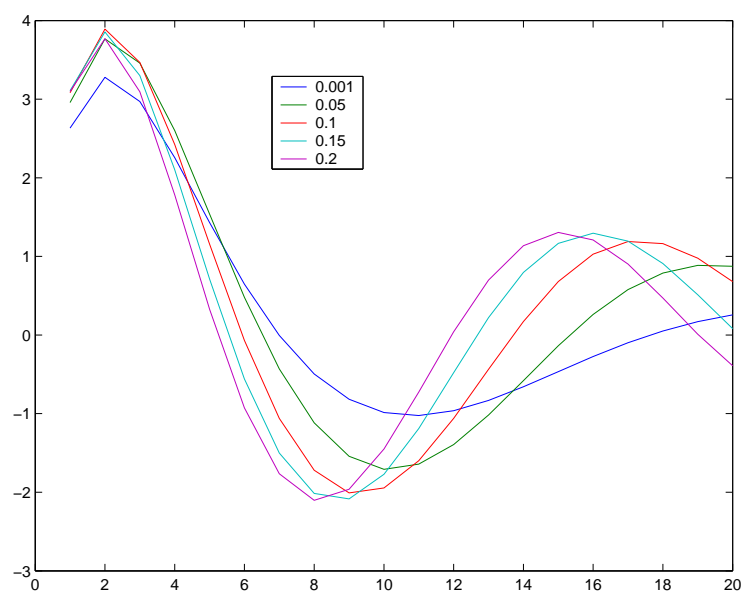

(a) unit output shock

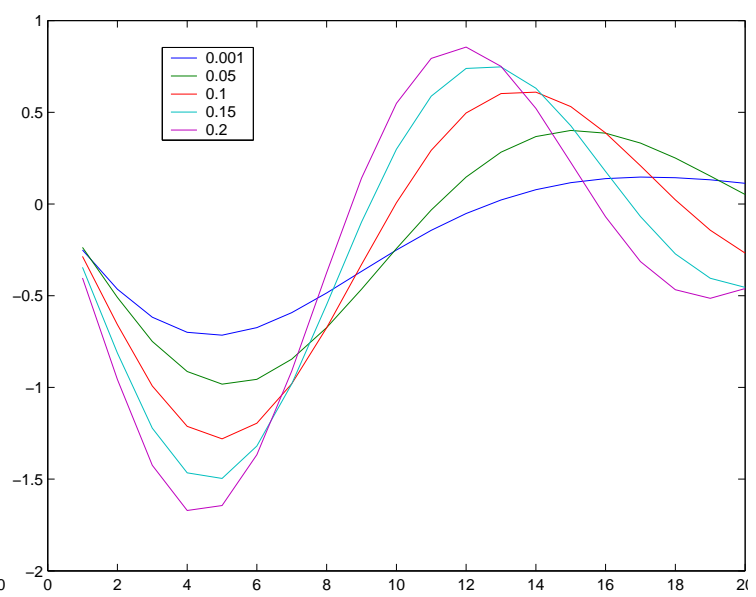

(b) unit inflation shock

Source: author

constitutes the best scenario. On the contrary, a deep and long recession in the aftermath of an asymmetric adverse supply shock can be expected in an economy with low market flexibility and high exposition to real exchange rate variations.

Turning to real interest rate effect determinants, Figure 13 suggests that lower (in absolute terms) estimates of output gap sensitivity to real interest rate $\left(\beta_{r}\right)$ support the adjustment process after asymmetric shocks, at least with baseline values of other parameters. This means that, given the baseline parametrisation, stabilizing effects of the common monetary policy on the country level are outweighed by procyclical effects from inflation expectations growth when the shock is asymmetric, confirming the existence of the real interest rate effect. Intuitively (and in line with the literature) this is especially the case when inflation expectations are highly backward-looking and/or a country is very small ${ }^{20}$. Consequences of a monetary policy response to an asymmetric shock in a large, dominating economy might be different. In such a case, monetary policy might more effectively stabilize with higher $\beta_{r}{ }^{21}$. Summing up, low or insignificant estimates of $\beta_{r}$ obtained from the data are good news, given a high degree of inflation persistence in an economy, but would be welcome in a big economy with strongly rational expectations.

The sensitivity to $\beta_{r}$ might be reduced not only by lower inflation persistence or higher country size. In Figure 14, we present the interdependencies between real interest and real exchange rate parameters in the IS curve, along with their impact on the the path of macroeconomic adjustment. The simulations performed confirm an important role of the competitiveness channel in a monetary union, especially when the negative link between the real rate of interest and the output gap is stronger. Strong responsiveness of the output gap to excess appreciation or depreciacion of a country's real exchange rate makes the economy more indifferent to $\beta_{r}$. As $\beta_{c}$ is high and significant in most of the cases in our estimates, this suggests that the real interest rate effect can be partially suppressed by the real exchange rate channel even in the short run.

Finally, a high share of exports in domestic production, translating into high dependence on foreign demand, acts in a dual way. Whenever a country is hit by an asymmetric shock, the influence of its demand on other monetary union economies helps to trigger a smoother common monetary policy action, supporting the adjustment process. However, an asymmetric shock abroad, combined with high $\beta_{s}$ at home, implies more disturbance to domestic economy. Bottom line, not much sensitivity

\footnotetext{
${ }^{20}$ With growing country weight, the path is more indifferent to $\beta_{r}$. Simulations are available upon request.

${ }^{21}$ Note that this is not the case for country sizes typical for the euro area. Again, institutional nuances that might finally result in different country weights are assumed away; see Kosior et al. (2008) for more discussion.
} 
Figure 14: Output responses with different real exchange and interest rate $\left(\beta_{c}\right.$ and $\left.\beta_{r}\right)$ parameter $\operatorname{mix}$

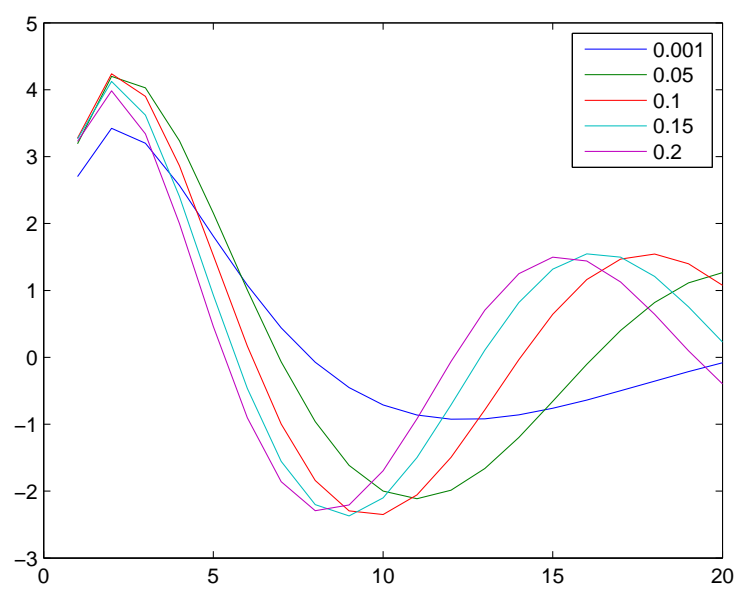

(a) unit output shock

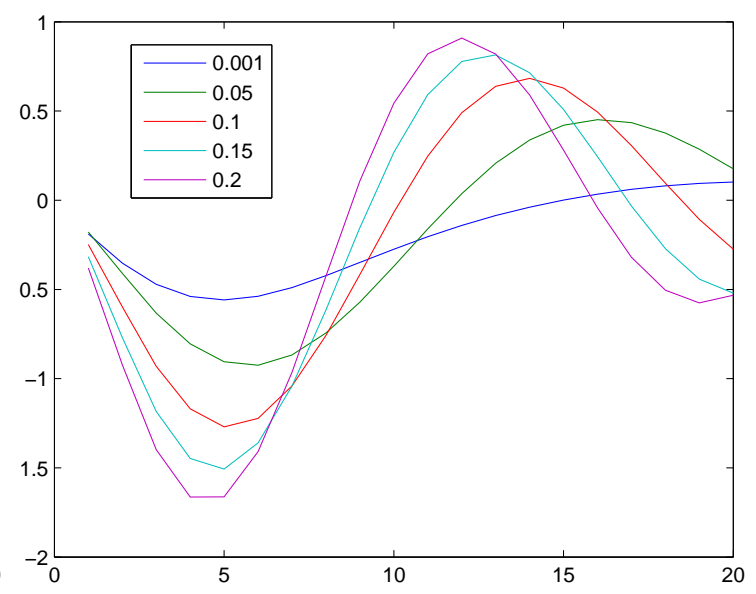

(b) unit output shock

various real interest rate parameters and weak competitiveness channel $(=0.02)$

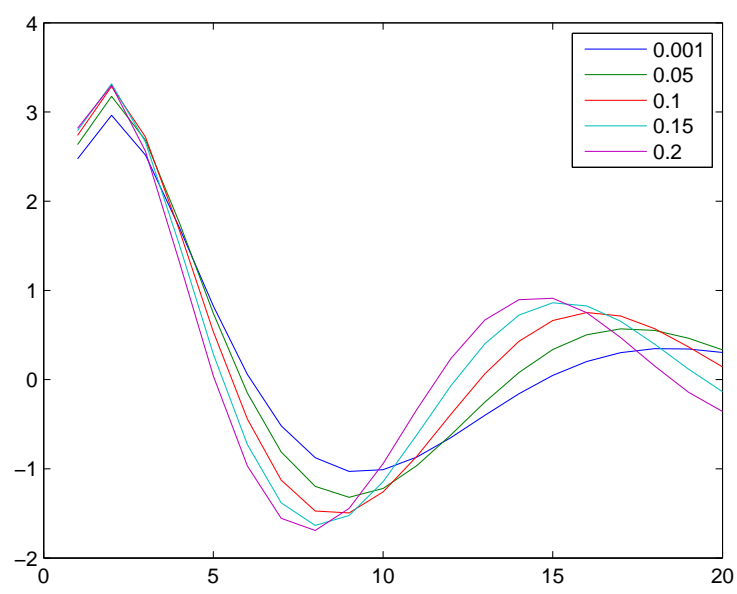

(c) unit output shock

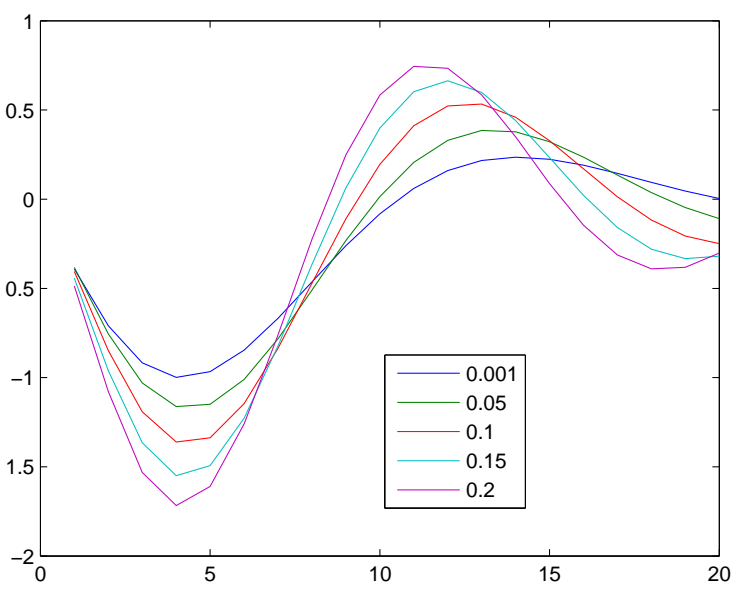

(d) unit output shock

various real interest rate parameters and strong competitiveness channel $(=0.1)$

Figure 15: Output adjustment sensitivity to foreign output gap parameter $\left(\beta_{s}\right.$ in $\left.(8)\right)$

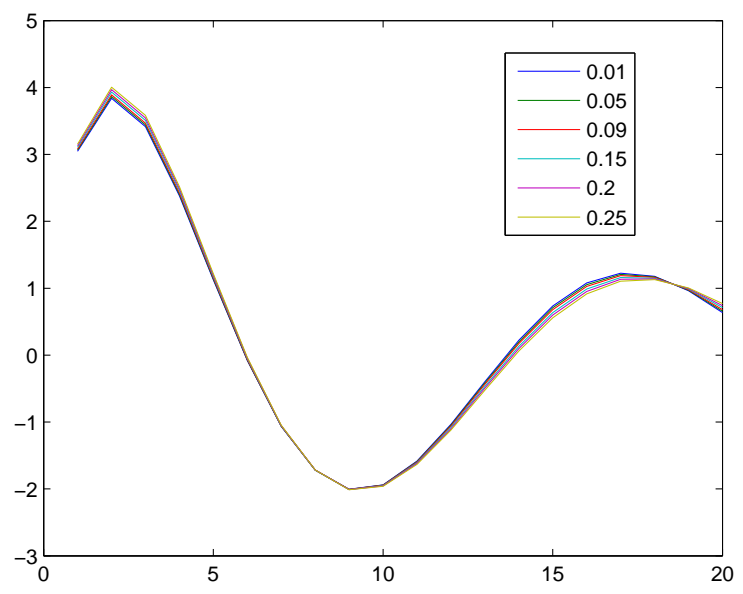

(a) unit output shock

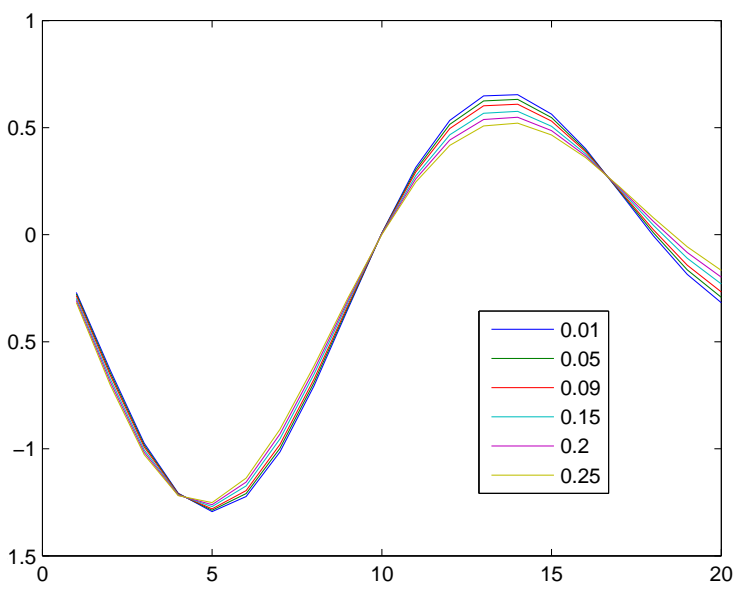

(b) unit output shock

Source: author 
with respect to $\beta_{s}$ itself is visible in Figure 15, although it is definitely helpful in interactions with other parameters in triggering common monetary policy reactions when we look at the entire monetary union.

\section{Conclusions}

This paper proposes a stylized New Keynesian model of a monetary union, incorporating both the competitiveness channel and the real interest rate mechanism. It spans countries, heterogenous in terms of IS and Phillips curves, with a single monetary policy approximated by a Taylor rule operating on aggregated inflation and output gaps. Rational expectations with respect both to future inflation and output gap are included in the model, and the algorithm of Söderlind (1999), based on Schur decomposition and generalized to the case of a monetary union of any size, is used to solve the model. We show that neither heterogenous natural rates of interest nor countryspecific steady-state inflation targets (associated with Balassa-Samuelson effect) prevent the system from restoring equilibrium, as one-off movements in price levels, associated with real appreciation or depreciation, offset the impact of common nominal interest rate and country-specific natural interest rates or inflation targets.

The smoothness and speed of adjustment after an asymmetric shock is strongly connected with heterogeneity in parameters, both in the country where the shock occurs and abroad. Our model confirms the widespread view that increasing country size supports the adjustment process with increasing reaction of common monetary policy. However, over the realistic range of country sizes in the euro area, other aspects of heterogeneity play the crucial role in the adjustment process.

The risk of cycle amplification, resulting from the real interest rate effect, is particularly high when expectations (especially inflation expectations) are highly backward-looking and rational only to a limited extent. It is particularly reinforced when the output gap is highly sensitive to countryspecific (i.e. based on country level inflation expectations) real interest rate. Persistence in output gap and small country size are further risk factors. Empirically, most of the estimates of output gap responsiveness to country-specific real interest rates in EMU-12 countries are low or insignificant, showing that the risk is concentrated on the side of expectations formation mechanism.

After asymmetric demand shocks, the real exchange rate channel is particularly effective as a stabilizing mechanism when (i) markets are highly flexible (which does not seem to be the case in the light of EMU-12 estimates) and (ii) the output gap responds strongly to real apprecation or depreciation. Our estimates show that the latter condition is fulfilled in most of the countries. When an asymmetric adverse supply shock occurs, the best combination possible is an economy where the output gap is less sensitive to real exchange rate dynamics and markets are very flexible. In an economy highly sensitive to real exchange rate over- or undervaluation, rigid markets can result in a prolongued, deep recession necessary to restore competitiveness. Foreign price flexibility does not seem to play a critical role in domestic adjustment process, suggesting that relative advantage in market flexibility over other countries as such is not significant for the adjustment dynamics. Last but not least, rising rationality of expectations (both with respect to output gap and inflation) is a factor strongly supporting competitiveness mechanism as an adjustment channel.

A number of questions arise for future research. Longer time series would make the GMM estimates more reliable. Further extensions of the model, such as explicit inclusion of 2 sectors in each economy and labour market rigidities, could allow to take further insights into the adjustment process, especially on the empirical level. Also, as suggested by European Commission (2006) estimates, downward nominal rigidities are a greater problem in EMU than upward price adjustments, whereby in this paper upward- and downward ones were treated symetrically. Finally, this paper suggests that empirical studies on expectation formation mechanism are critical for assessing the risk of real interest rate effect and overshooting in the adjsutment process. 


\section{References}

Afonso A., Furceri D. (2007): Business cycle synchronization and insurance mechanisms in the EU, ECB Working Paper Series.

Altissimo F., Benigno P., Palenzuela D.R. (2005): Long-run determinants of inflation differentials in a monetary union, CEPR Discussion Paper.

Andersen T.M. (2005): Heterogenous Wage Formation Under a Common Monetary Policy, CEPR Discussion Paper.

Angeloni I., Ehrmann M. (2004): Euro-area inflation differentials, ECB Working Paper Series.

Arnold I.J., Kool C.J. (2004): The role of inflation differentials in regional adjustment: evidence from the United States, Kredit und Kapital.

Arnold I.J.M., Lemmen J.J.G. (2006): Inflation expectations and inflation uncertainty in the eurozone: evidence from survey data, CESifo Working Paper.

Asdrubali P., Sorensen B.E., Yosha O. (1996): Channels of interstate risk sharing: United States 1963-1990, The Quarterly Journal of Economics.

Beck G.W., Hubrich K., Marcellino M. (2006): Regional inflation dynamics within and across euro area countries and a comparison with the US, ECB Working Paper.

Benati L. (2008): Investigating inflation persistence across monetary regimes, ECB Working Paper Series.

Borowski J. (2001): Podatność Polski na szoki asymetryczne a proces akcesji do Unii Gospodarczej $i$ Walutowej, Bank i Kredyt, (11-12).

Brissimis S.N., Skotida I. (2008): Optimal monetary policy in the euro area in the presence of heterogeneity, Journal of International Money and Finance.

Calmfors L. (ed.) (2007): The EEAG report on the european economy 2007, CESifo.

Calmfors L., Johansson A. (2002): Nominal wage flexibility, wage indexation and monetary union, Institute for International Economic Studies Seminar Paper.

Calvo G. (1983): Staggered prices in a utility-maximizing framework, Journal of Monetary Economics, 12(3).

Campolmi A., Faia E. (2007): Labor Market Institutions and Inflation Volatility in the Euro Area.

Canzoneri M.B., Cumby R.E., Diba B.T., Mykhaylova O. (2005): New Keynesian Explanations of Cyclical Movements in Aggregate Inflation and Regional Inflation Differentials, Open Economies Review.

Catao L., Mackenzie G.A. (2006): Perspectives on Low Global Interest Rates, IMF Working Paper.

Clarida R., Gali J., Gertler M. (2001): Optimal Monetary Policy in Open versus Closed Economies: An Integrated Approach, American Economic Review.

Clausen V., Hayo B. (2006): Asymmetric monetary policy effects in EMU, Applied Economics.

de Grauwe P. (2005): Economics of Monetary Union, Oxford University Press.

Deroose S., Langedijk S., Roeger W. (2004): Reviewing adjustment dynamics in EMU: from overheating to overcooling, European Commission DG ECFIN.

European Central Bank (2003): Inflation differentials in the euro area: potential causes and policy implications. 
European Central Bank (2006): Differences in MFI interest rates across euro area countries.

European Central Bank (May 2005): Monetary policy and inflation differentials in a heterogenous currency area, ECB Monthly Bulletin.

European Commission (2006): The EU economy: 2006 review. Adjustment dynamics in the euro area - Experiences and challenges.

European Commission (2008): EMU@10. Successes and challenges after 10 years of Economic and Monetary Union, European Economy.

Everaert L., Schule W. (2006): Structural Reforms in the Euro Area: Economic Impact and Role of Synchronization Across Markets and Countries, IMF Working Paper.

Galí J., Gertler M. (1999): Inflation dynamics: A structural econometric analysis, Journal of Monetary Economics, 44, 195-222.

Goodhart C., Hofmann B. (2005): The Phillips Curve, the IS Curve and Monetary Transmission: Evidence for the US and the Euro Area, CESifo Economic Studies.

HM Treasury (2003): UK membership of the single currency. An assessment of the five economic tests.

Hoeller P., Giorno C., de la Maisonneuve C. (2002): Overheating in Small Euro Area Economies. Should fiscal policy react?, OECD Economics Department Working Paper.

Hoeller P., Giorno C., de la Maisonneuve C. (2004): One money, one cycle? Making a monetary union a smoother ride, OECD Economics Department Working Paper.

Hoeller P., Rae D. (2007): Housing Markets and Adjustment in Monetary Union, OECD Economics Department Working Papers.

Hofmann B., Remsperger H. (2005): Inflation Differentials among the Euro Area Countries: Potential Causes and Consequences, Journal of Asian Economics.

Honohan P., Lane P. (2003): Divergent inflation rates in EMU, Economic Policy.

Honohan P., Lane P. (2004): Exchange Rates and Inflation under EMU: An Update, CEPR Discussion Paper.

Honohan P., Leddin A. (2005): Ireland in EMU: more shocks, less insulation?, CEPR Discussion Paper.

Imbs J. (2004): Trade, finance, specialization and synchronization, The Review of Economics and Statistics.

Kalemli-Ozcan S., Sorensen B.E., Yosha O. (2001): Economic Integration, Industrial Specialization, and the Asymmetry of Macroeconomic Fluctuations, Journal of International Economics.

Kalemli-Ozcan S., Sorensen B.E., Yosha O. (2003): Risk Sharing and Industrial Specialization: Regional and International Evidence.

Kalemli-Ozcan S., Sorensen B.E., Yosha O. (2004): Asymmetric Shocks and Risk Sharing in a Monetary Union: Updated Evidence and Policy Implications for Europe.

Kosior A., Rozkrut M., Torój A. (2008): Ocena systemu głosowania rotacyjnego w Radzie Prezesów - efektywność polityki pieniężnej $i$ wpływ przedstawicieli Polski na proces decyzyjny $E B C$, forthcoming.

Lane P.R. (2006): The Real Effects of EMU, Journal of Economic Perspectives.

Langedijk S., Roeger W. (2007): A model-based analysis of country experiences, European Commission DG ECFIN. 
Lindé J. (2005): Estimating New-Keynesian Phillips curves: A full information maximum likelihood approach, Journal of Monetary Economics.

Lopez-Salido J., Restoy F., Vallés J. (2005): Inflation differentials in EMU: the Spanish case, Banco de España Working Paper.

MacDonald R., Wójcik C. (2006): Inflation Differentials in the Euro Area in a New Neoclassical Synthesis Framework, Bank i Kredyt.

Marzinotto B. (2007): Why so much wage restraint in EMU? The role of country size, preliminary draft.

OECD (2004): Employment Outlook.

Pisani-Ferry J., Aghion P., Belka M., Hagen J.V., Heikensten L., Sapir A. (2008): Coming of age: report on the euro area, Bruegel.

Remsperger H., Hofmann B. (2005): Inflation differentials anmon the euro area countreis: potential causes and consequences, Journal of Asian Economics.

Roubini N., Parisi-Capone E., Menegatti C. (2007): Growth Differentials in the EMU: Facts and Considerations.

Rumler F. (2007): Estimates of the Open Economy New Keynesian Phillips Curve for Euro Area Countries, Open Economies Review.

Sauer S., Sturm J.E. (2003): Using Taylor Rules to Understand ECB Monetary Policy, CESifo Working Paper.

Söderlind P. (1999): Solution and estimation of RE macromodels with optimal policy, European Economic Review, (43), 813-823.

Taylor J.B. (1993): Discretion versus policy rules in practice, Carnegie-Rochester Conference Series on Public Policy.

Traistaru-Siedschlag I. (2006): Macroeconomic differentials and adjustment in the euro area, The Economic and Social Research Institute.

van den Noord P. (2004): Modelling cyclical divergence in the euro area: the housing channel, OECD Economics Department Working Papers, (400).

von Hagen J., Hofmann B. (2004): Macroeconomic implications of low inflation in the euro area, North American Journal of Economics and Finance.

Walters A. (1994): The Economics and Politics of Money: The. Selected Essays of Alan Walters, chapter Walters Critique, U.K. Elgar.

Wicksell K. (1907): The Influence of the Rate of Interest on Prices, The Economic Journal.

Wójcik C. (2008): Integracja ze strefa euro, PWN.

Woodford M. (2006): Interpreting Inflation Persistence: Comments on the Conference on "Quantitative Evidence on Price Determination", Journal of Money, Credit and Banking. 


\section{Appendix A - Solving the model with rational expectations}

To solve the model with rational expectations, we apply an algorithm proposed by Söderlind (1999). We write the model as

$$
A_{0}\left[\begin{array}{c}
x_{1, t+1} \\
E_{t} x_{2, t+1}
\end{array}\right]=A_{1}\left[\begin{array}{l}
x_{1, t} \\
x_{2, t}
\end{array}\right]-B F\left[\begin{array}{c}
x_{1, t} \\
x_{2, t}
\end{array}\right]+\left[\begin{array}{c}
\eta_{t+1} \\
0
\end{array}\right]
$$

with

$$
\boldsymbol{x}_{\mathbf{1 , t}}=\left[\begin{array}{c}
1 \\
t \\
P_{1, t} \\
\vdots \\
P_{12, t} \\
\varepsilon_{\pi, 1, t} \\
\vdots \\
\varepsilon_{\pi, 12, t} \\
\varepsilon_{y, 1, t} \\
\vdots \\
\varepsilon_{y, 12, t} \\
\varepsilon_{R, t} \\
\pi_{1, t} \\
\vdots \\
\pi_{12, t} \\
y_{1, t} \\
\vdots \\
y_{12, t} \\
i_{t}
\end{array}\right] \quad \boldsymbol{x}_{2, t}=\left[\begin{array}{c}
\pi_{1, t} \\
\vdots \\
\pi_{12, t} \\
y_{1, t} \\
\vdots \\
y_{12, t}
\end{array}\right]
$$$$
\boldsymbol{\eta}_{\boldsymbol{t + 1}}=\left[\begin{array}{c}
\mathbf{0}_{\mathbf{1 4 \times \mathbf { 1 }}} \\
\eta_{\pi, 1, t+1} \\
\vdots \\
\eta_{\pi, 12, t+1} \\
\eta_{y, 1, t+1} \\
\vdots \\
\eta_{y, 12, t+1} \\
\eta_{i, t+1} \\
\mathbf{0}_{\mathbf{2 5 \times \mathbf { 1 }}}
\end{array}\right]
$$

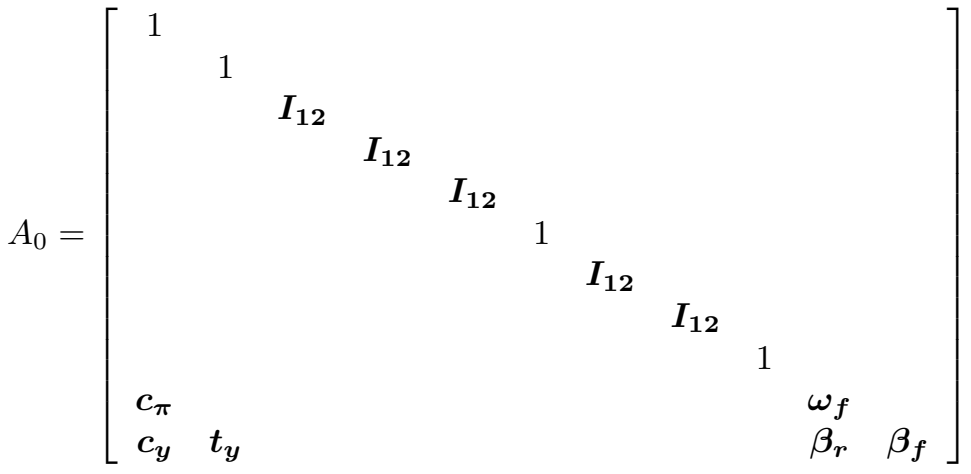

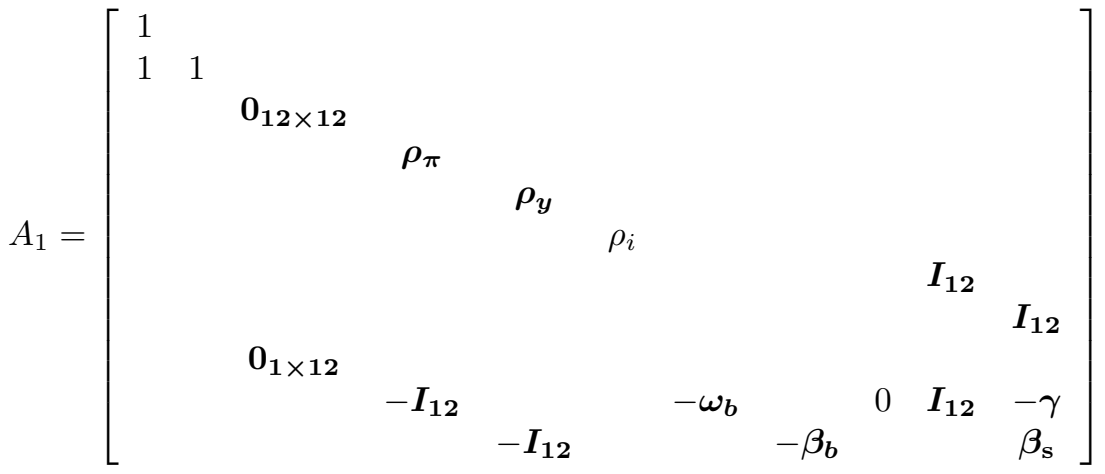


$B=\left[\begin{array}{cc}I_{12} & \\ & \\ & 1 \\ \beta_{c} \cdot \mathbf{1}_{12 \times 1} & \beta_{r} \cdot \mathbf{1}_{12 \times 1}\end{array}\right]$

$\boldsymbol{c}_{\boldsymbol{\pi}}=\left[\begin{array}{c}\left(1-\omega_{b, 1}-\omega_{f, 1}\right) \pi_{1}^{*} \\ \left(1-\omega_{b, 2}-\omega_{f, 2}\right) \pi_{2}^{*} \\ \vdots \\ \left(1-\omega_{b, 12}-\omega_{f, 12}\right) \pi_{12}^{*}\end{array}\right]$

$\boldsymbol{\omega}_{\boldsymbol{f}}=\left[\begin{array}{llll}\omega_{f, 1} & & & \\ & \omega_{f, 2} & & \\ & & \ddots & \\ & & & \omega_{f, 12}\end{array}\right]$

$\boldsymbol{\beta}_{\boldsymbol{f}}=\left[\begin{array}{llll}\beta_{f, 1} & & & \\ & \beta_{f, 2} & & \\ & & \ddots & \\ & & & \beta_{f, 12}\end{array}\right]$

$\boldsymbol{\beta}_{\boldsymbol{r}}=\left[\begin{array}{llll}\beta_{r, 1} & & & \\ & \beta_{r, 2} & & \\ & & \ddots & \\ & & & \beta_{r, 12}\end{array}\right]$

$\boldsymbol{\beta}_{\boldsymbol{s}}=\left[\begin{array}{cccc}1 & -\beta_{s, 1} \frac{w_{2}}{1-w_{1}} & \ldots & -\beta_{s, 1} \frac{w_{12}}{1-w_{1}} \\ -\beta_{s, 2} \frac{w_{1}}{1-w_{2}} & 1 & \ldots & -\beta_{s, 2} \frac{w_{12}}{1-w_{2}} \\ \vdots & \vdots & \ddots & \vdots \\ -\beta_{s, 12} \frac{w_{1}}{1-w_{12}} & -\beta_{s, 12} \frac{w_{2}}{1-w_{12}} & \cdots & 1\end{array}\right]$

$\boldsymbol{\beta}_{\mathbf{c}}=\left[\begin{array}{cccc}\beta_{c, 1} & -\beta_{c, 1} \frac{w_{2}}{1-w_{1}} & \ldots & -\beta_{c, 1} \frac{w_{12}}{1-w_{1}} \\ -\beta_{c, 2} \frac{w_{1}}{1-w_{2}} & \beta_{c, 2} & \ldots & -\beta_{c, 2} \frac{w_{12}}{1-w_{2}} \\ \vdots & \vdots & \ddots & \vdots \\ -\beta_{c, 12 \frac{w_{1}}{1-w_{12}}} & -\beta_{c, 12 \frac{w_{2}}{1-w_{12}}} & \cdots & \beta_{c, 12}\end{array}\right]$

$\boldsymbol{\rho}_{\pi}=\left[\begin{array}{cccc}\rho_{\pi, 1} & & & \\ & \rho_{\pi, 2} & & \\ & & \ddots & \\ & & & \rho_{\pi, 12}\end{array}\right]$

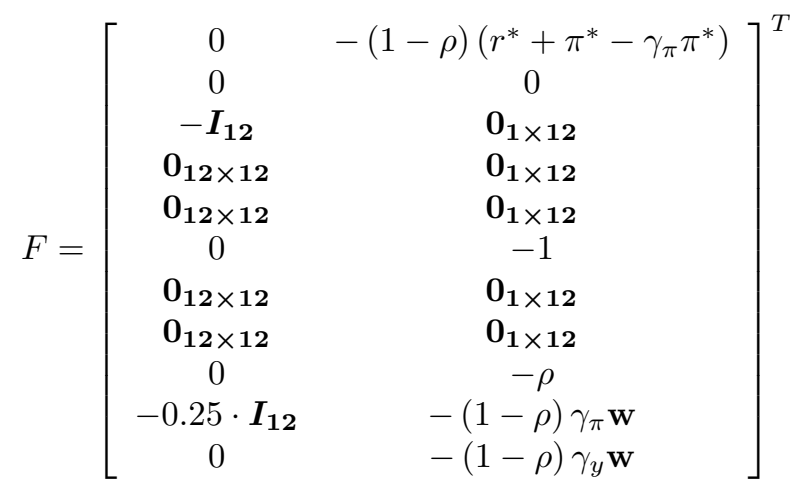

$\boldsymbol{c}_{\boldsymbol{y}}=\left[\begin{array}{c}\beta_{r, 1} r_{1}^{*} \\ \beta_{r, 2} r_{2}^{*} \\ \vdots \\ \beta_{r, 12} r_{12}^{*}\end{array}\right] \quad \boldsymbol{t}_{\boldsymbol{y}}=0.25\left[\begin{array}{c}\beta_{c, 1}\left(\pi_{1}^{*}-\pi_{-1}^{*}\right) \\ \beta_{c, 2}\left(\pi_{2}^{*}-\pi_{-2}^{*}\right) \\ \vdots \\ \beta_{c, 12}\left(\pi_{12}^{*}-\pi_{-12}^{*}\right)\end{array}\right]$

$\boldsymbol{\omega}_{\boldsymbol{b}}=\left[\begin{array}{cccc}\omega_{b, 1} & & & \\ & \omega_{b, 2} & & \\ & & \ddots & \\ & & & \omega_{b, 12}\end{array}\right]$

$\boldsymbol{\beta}_{\boldsymbol{b}}=\left[\begin{array}{cccc}\beta_{b, 1} & & & \\ & \beta_{b, 2} & & \\ & & \ddots & \\ & & & \beta_{b, 12}\end{array}\right]$

$\gamma=\left[\begin{array}{llll}\gamma_{1} & & & \\ & \gamma_{2} & & \\ & & \ddots & \\ & & & \gamma_{12}\end{array}\right]$

We use matrix $A=A_{0}^{-1}\left(A_{1}-B F\right)$ as input for the algorithm and reject unstable roots (eigenvalues $>1)$. The solution with respect to forward looking variables is obtained. 